\title{
Dictyostelium: An Important Source of Structural and Functional Diversity in Drug Discovery
}

\author{
Yuzuru Kubohara ${ }^{1, *(1)}$ and Haruhisa Kikuchi ${ }^{2}$ (1) \\ 1 Laboratory of Health and Life Science, Graduate School of Health and Sports Science, Juntendo University, \\ Inzai, Chiba 270-1695, Japan \\ 2 Laboratory of Natural Product Chemistry, Graduate School of Pharmaceutical Sciences, Tohoku University, \\ 6-3 Aza-aoba, Aramaki, Aoba-ku, Sendai 980-8578, Japan; hal@mail.pharm.tohoku.ac.jp \\ * Correspondence: ykuboha@juntendo.ac.jp; Tel.: +81-476-98-1001 (ext. 384)
}

Received: 5 December 2018; Accepted: 19 December 2018; Published: 21 December 2018

\begin{abstract}
The cellular slime mold Dictyostelium discoideum is an excellent model organism for the study of cell and developmental biology because of its simple life cycle and ease of use. Recent findings suggest that Dictyostelium and possibly other genera of cellular slime molds, are potential sources of novel lead compounds for pharmacological and medical research. In this review, we present supporting evidence that cellular slime molds are an untapped source of lead compounds by examining the discovery and functions of polyketide differentiation-inducing factor- 1 , a compound that was originally isolated as an inducer of stalk-cell differentiation in D. discoideum and, together with its derivatives, is now a promising lead compound for drug discovery in several areas. We also review other novel compounds, including secondary metabolites, that have been isolated from cellular slime molds.
\end{abstract}

Keywords: Dictyostelium; Polysphondylium; cellular slime mold; DIF; polyketide; drug resource; mitochondria; cancer; diabetes; Trypanosoma cruzi

\section{Introduction}

Natural products have been used as medicines and for drug development since ancient times and natural product chemistry remains important in the fields of drug discovery, structure elucidation and chemical synthesis. Among the current sources of lead compounds for drug discovery, microorganisms such as the fungi ascomycetes, basidiomycetes and deuteromycetes and the bacteria actinomycetes, have provided many useful drugs (e.g., antibiotics) [1-3]. Currently, in the field of medicine there are several major issues that need to be addressed, such as the development of drugs with improved adverse effect profiles; drugs to treat currently incurable diseases; and drugs against refractory bacteria, protozoans and cancer cells [1-4]. Thus, novel sources of lead compounds are needed.

The cellular slime molds are a group of soil microorganisms that belong to the eukaryotic kingdom Amoebozoa, which, according to recent taxonomic research, is distinct from the fungus kingdom Mycota (Figure 1) [5-7]. For about 80 years, the cellular slime mold Dictyostelium discoideum has been used as a model organism for the study of eukaryotic cell functions (e.g., division, differentiation, chemotaxis, autophagy and death) [8-19] mainly because of its simple life cycle and ease of handling. Recently, $D$. discoideum has also been used as a model organism for the study of human diseases and estimation of drug effects [17,20-24]. (See the other reviews in this special issue). Our group has been examining the use of cellular slime molds as a source of natural compounds and we have isolated several novel biologically significant compounds from several species of cellular slime molds [25-34]. 


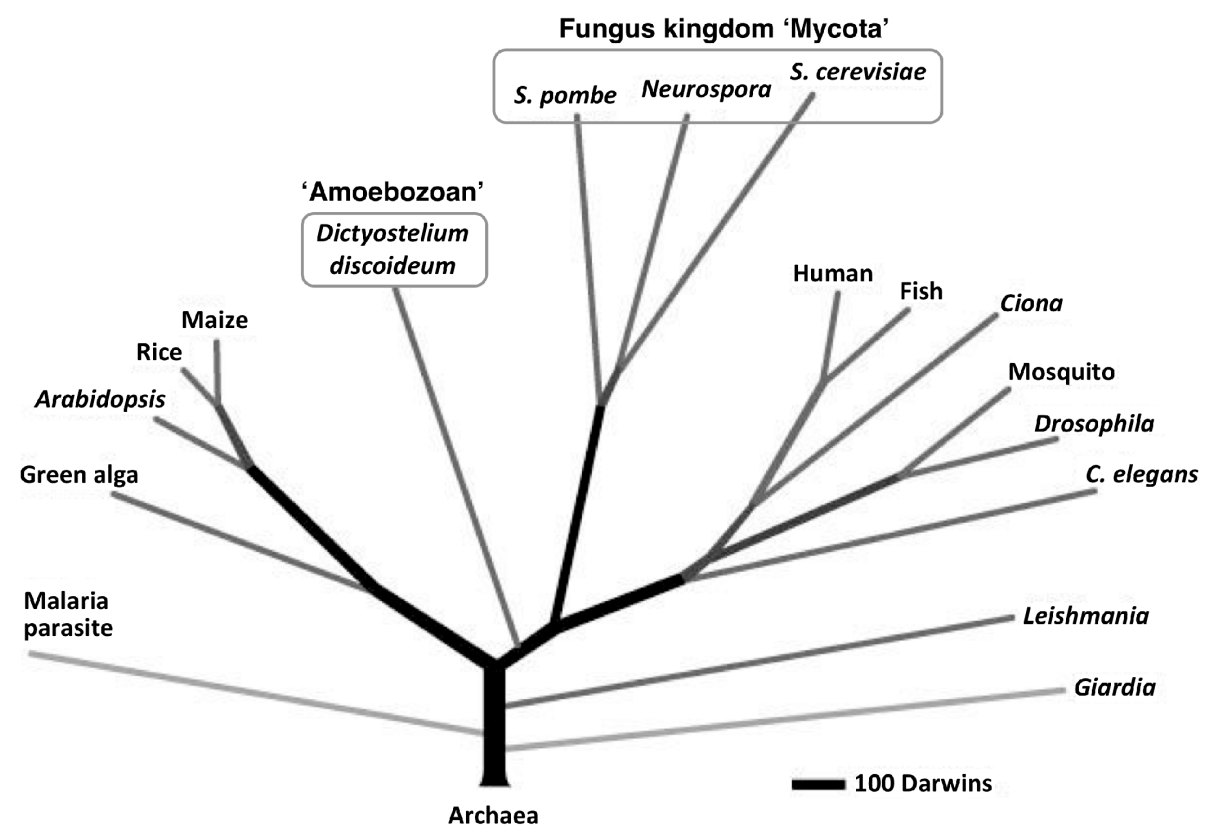

Figure 1. Proteome-based eukaryotic phylogeny (adapted with permission from Eichinger et al. [6]). The phylogenetic tree was constructed from a database of 5279 orthologous protein clusters that were drawn from 17 eukaryotic proteomes, including that of Dictyostelium discoideum, which was rooted on 159 protein clusters that had representatives from six archaebacterial proteomes: Plasmodium falciparum, malaria parasite; Chlamydomonas reinhardtii, green alga; Oryza sativa, rice; Zea mays, maize; Fugu rubripes, fish; Anopheles gambiae, mosquito.

Genome analyses of Dictyostelium cellular slime molds have revealed that $D$. discoideum has approximately 43 polyketide synthase genes [6] and that $D$. purpureum has 50 predicted polyketide synthase genes [35]. These numbers of polyketide synthase genes are greater than those in Streptomyces avermitilis, which is a bacterium known to produce many secondary metabolites; here, secondary metabolites are organic compounds biosynthesized from primary metabolites by taxonomically restricted spectrum of organism and not directly necessary for their growth and reproduction. This suggests that Dictyostelium cellular slime molds and possibly other genera of cellular slime molds [30,32], also produce an abundance of secondary metabolites that could be used as novel lead compounds for drug discovery.

Among the data on the candidate lead compounds our group has reported to date, we have made most progress regarding elucidation of the biological and pharmacological activities of the D. discoideum differentiation-inducing factors.

\section{Biological and Pharmacological Activities of DIF-1 and Its Derivatives}

\subsection{Functions of DIF-1, DIF-2 and DIF-3 in D. discoideum}

DIF-1 (differentiation-inducing factor 1), DIF-2 and DIF-3 (Figure 2A) are chlorinated alkylphenones that were originally isolated from $D$. discoideum as inducers of stalk-cell differentiation [36,37]. Of the three compounds, DIF-1 is the most active so that DIF- 1 at nanomolar levels dose-dependently induces stalk-cell differentiation in vitro; DIF-2 has only around $40 \%$ of the specific activity of DIF-1 [37-40] and DIF- 3 has only around $4 \%$ of the activity of DIF- 140,41$]$, although DIF- 3 is the initial metabolite of DIF-1 in vivo [40,42]. Stalk cell differentiation is a sort of programmed cell death [43] and can be categorized as a type of autophagic cell death [11,44]. Therefore, DIF-1-induced stalk-cell differentiation is a good model system for the study of autophagy, autophagic cell death and programmed cell death [45-47]. 
In addition to having differentiation-inducing activities, DIFs 1 and 2 at nanomolar levels function as modulators for Dictyostelium chemotactic cell movement toward cyclic adenosine monophosphate (cAMP) [48,49]. Importantly, the mechanisms for the modulation of chemotaxis by DIFs differ, at least in part, from those for the induction of stalk-cell differentiation [48-50]. Since the discovery of DIFs 1 and 2, the mechanisms underlying their functions have been examined [11,41,44-57] but remain to be fully elucidated; most importantly, their receptors have not been determined.

It is important to note that DIFs 1 and 2 are endogenous polyketide factors in D. discoideum and DIF-3 is a metabolite $[40,42,58]$; they were not identified as drugs against human diseases such as antibiotics at first.

\section{A}

DIF-1<smiles>CCCCCC(=O)c1c(O)c(Cl)c(OC)c(Cl)c1O</smiles>

B

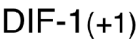<smiles>CCCCCCC(=O)c1c(O)c(Cl)c(OC)c(Cl)c1O</smiles>

DIF-3(+1)<smiles>CCCCCCC(=O)c1c(O)cc(OC)c(Cl)c1O</smiles>

DIF-3(-1)<smiles>CCCCC(=O)c1c(O)cc(OC)c(Cl)c1O</smiles>

DIF-2<smiles>CCCCC(=O)c1c(O)c(Cl)c(OC)c(Cl)c1O</smiles>

DIF-1(3M)<smiles>COc1c(Cl)c(O)c(C(=O)CC(C)(C)C)c(O)c1Cl</smiles>

DIF-3(3M)<smiles>COc1cc(O)c(C(=O)CC(C)(C)C)c(O)c1Cl</smiles>

TH-DIF-1<smiles>CCCCCC(=O)c1c(O)c(Cl)c(O)c(Cl)c1O</smiles>

DIF-3<smiles>CCCCCC(=O)c1c(O)cc(OC)c(Cl)c1O</smiles>

Differanisole A (DA)<smiles>CCCc1c(Cl)c(OC)c(Cl)c(O)c1C(=O)O</smiles>

Et-DIF-1<smiles>CCCCCC(=O)c1c(O)c(Cl)c(OCC)c(Cl)c1O</smiles>

Et-DIF-3<smiles>CCCCCC(=O)c1c(O)cc(OCC)c(Cl)c1O</smiles><smiles>CCCCCC(=O)c1c(O)cc(OCCCC)c(Cl)c1O</smiles>

TM-DIF-1<smiles>CCCCCC(=O)c1c(OC)c(Cl)c(OC)c(OC)c1OC</smiles>

Figure 2. (A) Chemical structures of DIFs 1-3 and differanisole A. The order of the stalk-cell differentiation-inducing activity in D. discoideum in vitro is DIF-1 > DIF-2 >> DIF-3 [39,40]; (B) Chemical structures of 11 representative DIF derivatives.

\subsection{Discovery of the Antitumor Activities of DIFs}

Two years before the discovery of DIF-1, Oka et al. [59] isolated a compound called differanisole A (DA) (Figure 2A) from the fungus Chaetomium (RB-001). DA induces growth arrest and re-differentiation of mouse erythroleukemia (B8) cells into hemoglobin-producing cells. On the basis of the structural similarity of DIF-1 and DA, it has been shown that DA (at high enough concentration) has the same effects as DIF-1 in D. discoideum [60], and, conversely, that DIF-1 at micromolar levels induces growth arrest and re-differentiation of mouse B8 cells into hemoglobin-producing cells in a dose-dependent manner [61]. Since the antitumor activity of DIF-1 is slightly higher than that of DA (unpublished observation), our group started to develop antitumor agents, utilizing DIF-1.

DIFs 1 and 3-especially DIF-3 - have strong anti-proliferative activity and induce or promote cell differentiation in various mammalian tumor cell lines in vitro, including human leukemia K562 cells, human myeloid leukemia HL-60 cells, human gastric cancer cells and human cervical cancer HeLa cells [61-66]. In addition, under certain conditions (e.g., at high concentrations), DIFs 1 and 3 can 
induce cell death [67-69]. Note that the anti-proliferative and differentiation-inducing effects of DIFs are not limited to transformed cells (see Section 2.4.1) [66,70-72]; however, the anti-proliferative effect of DIFs in transformed cells is stronger than that in mouse 3T3-L1 fibroblasts (a model non-transformed cell) $[71,72]$.

Our group has investigated the chemical structure-activity relationship of more than 30 chemically synthesized DIF derivatives (Figure 2B) and has found several DIF-3 derivatives (e.g., DIF-3(+1) and $\mathrm{Bu}-\mathrm{DIF}-3)$ that are potent suppressors of cell growth and are therefore promising compounds for the development of anti-cancer drugs (Figure 3) [72-75].
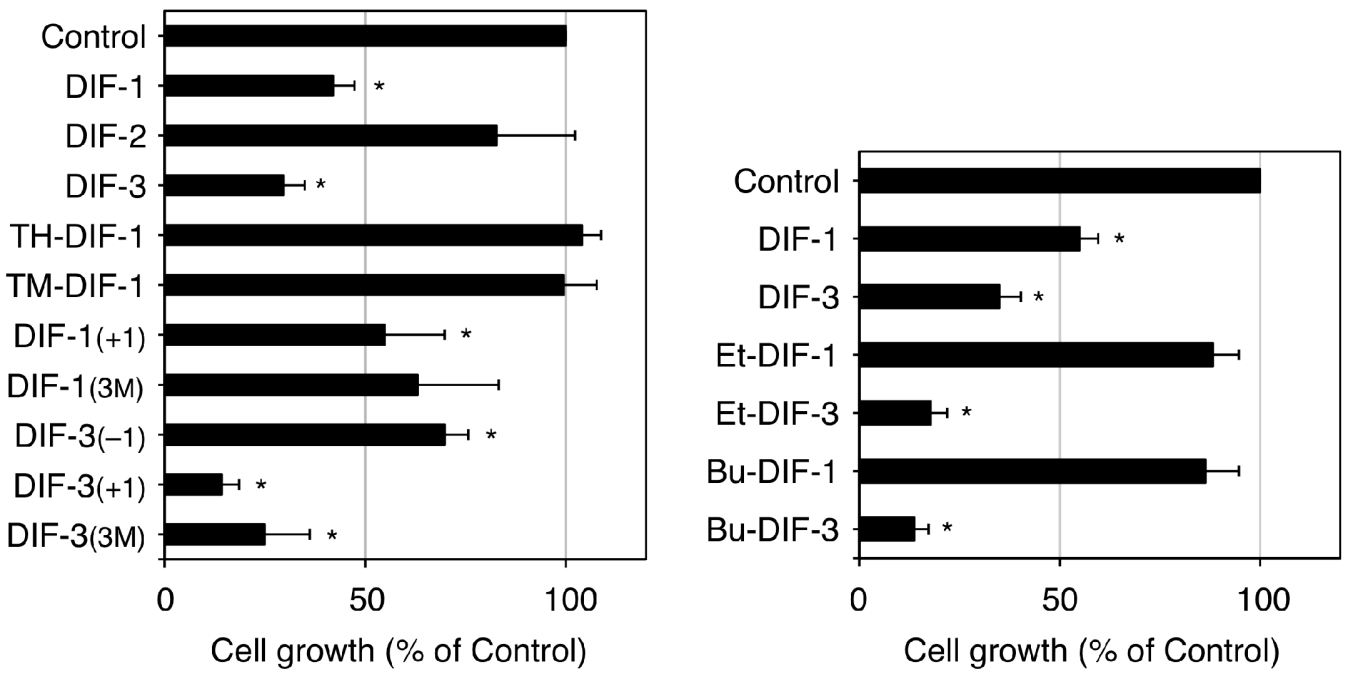

Figure 3. Effects of DIFs on the growth of K562 human leukemia cells (adapted from Gokan et al. [73]). Cells were incubated at $37^{\circ} \mathrm{C}$ for 3 days in the presence of $0.15 \% \mathrm{EtOH}$ (vehicle; Control) or $15 \mu \mathrm{M}$ of one of the DIF derivatives and then the relative cell number was assessed. Means and SD (bars) of three independent experiments are shown. ${ }^{*} p<0.05$ versus Control (by $t$-test; two-tailed, unpaired). DIF-3 and its derivatives but not DIF-1 and its derivatives, showed strong anti-proliferative activity in K562 cells.

The mechanisms underlying the antitumor activities of DIFs 1 and 3 and their derivatives have been partially elucidated (Figure 4); for example, it has been reported that (1) they rapidly increase intracellular calcium concentration in several tumor cell lines [62-64,68,69]; (2) they directly inhibit the activities of calmodulin-dependent cAMP/cGMP phosphodiesterase (PDE1) [76] and p21-activated kinase 1 (PAK1) [74]; (3) they function as mitochondrial uncouplers and disrupt mitochondrial functions, possibly resulting in the induction of mitophagy and autophagy [69,77]; (4) they affect the activities of several crucial enzymes such as phosphatidylinositol 3-kinase (PI3K) and Akt kinase (protein kinase B) [78], extracellular signal-regulated kinase (Erk) [65,79] and glycogen synthase kinase-3 $\beta$ (GSK-3 $\beta$ ) [66,80] in several tumor cell lines; and (5) they suppress the expression of cyclins $\mathrm{D} / \mathrm{E}$ and reduce the phosphorylation of retinoblastoma protein $(\mathrm{pRB})$, resulting in cell-cycle arrest at the $\mathrm{G}_{1} / \mathrm{G}_{0}$ phase $[70,79,81]$.

Recent studies have revealed that the DIFs inhibit cell migration in certain malignant cancer cell lines, such as mouse osteosarcoma LM8 cells and mouse (B16BL6) and human (A2058) melanoma cells, in vitro and in vivo (in mice) [72,82]. Also, DIF-3 inhibits intestinal tumor growth in vitro and in vivo (in mice) [83] and imatinib-resistant K562 leukemia cell growth in xenografted mice [69]. These observations suggest that DIFs have therapeutic potential for the treatment of malignant metastatic and drug-resistant cancers.

In the future, our group intends to elucidate the mechanisms underlying the actions of DIFs and develop DIF derivatives with more potent activities for use as lead compounds in anti-cancer drug discovery. 


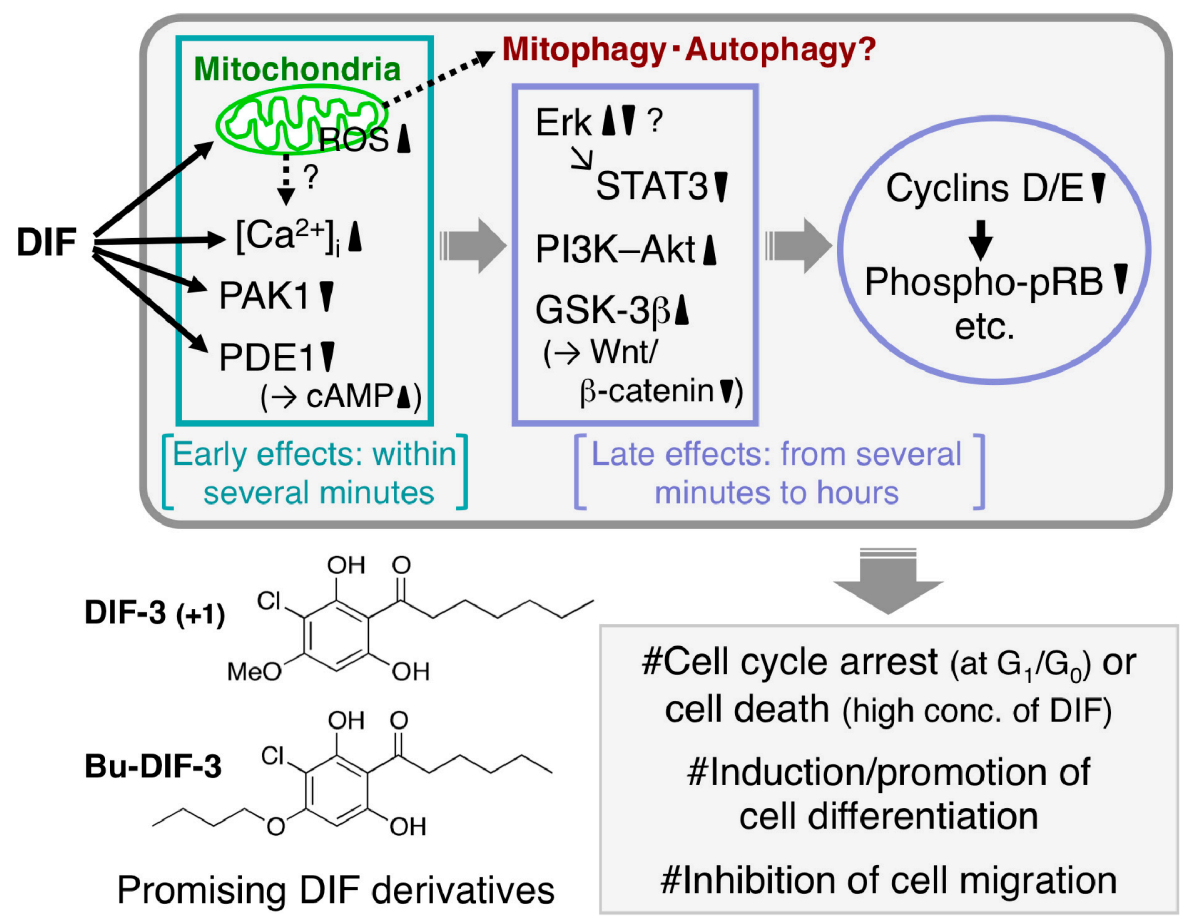

Figure 4. Proposed scheme of the antitumor effects of DIFs. After the addition of one of the DIFs to tumor cells, the DIF rapidly (within several minutes) disturbs mitochondrial function $[69,77]$, increases reactive oxygen species (ROS) production [69] and intracellular calcium concentration $\left(\left[\mathrm{Ca}^{2+}\right]_{\mathrm{i}}\right)[63,64,69,77]$ and inhibits the activities of p21-activated kinase 1 (PAK1) [74] and calmodulin-dependent cAMP/cGMP phosphodiesterase (PDE1) (resulting in an increase in cAMP levels) [76]. Over time (from several minutes to hours) the DIF also affects the activities of extracellular signal-regulated kinase (Erk), signal transducer and activator of transcription 3 (STAT3), phosphatidylinositol 3-kinase (PI3K)-Akt, glycogen synthase kinase-3 $\beta$ (GSK-3 $\beta$ ) and the Wnt/ $\beta$-catenin pathway, which suppresses the expression of cyclins D/E (and promotes the degradation of cyclin D1) and the subsequent reduction of phospho-pRB [65,66,74,77-81]. At appropriate concentrations the DIFs have been found to induce growth arrest in all the tumor cell lines tested to date in vitro and in vivo and at higher concentrations they have induced caspase-independent cell death [67-69]. Also, the DIFs induce differentiation of murine and human leukemia (B8 and K562) cells in vitro [61,64] and promote retinoic acid-induced differentiation of human leukemia HL-60 cells in vitro [63]. In addition, the DIFs suppress the migration of some cancer cells in vitro and in vivo [72,82]. Chemical structure-activity relationship analyses have revealed that DIF-3(+1) and Bu-DIF-3 are promising lead compounds for the development of anti-cancer drugs [72-74].

\subsection{Glucose Uptake-Promoting Activity of DIF-1}

As the first step to assessing the potential of using DIF-1 as a lead compound for anti-cancer drug development, our group investigated the toxic effects of DIF-1 in vitro by using confluent mouse 3T3-L1 fibroblasts and rat gastric mucosal RGM-1 cells, which are model non-transformed cell lines [84]. DIF-1 at 5-20 $\mu \mathrm{M}$ dose-dependently promoted glucose uptake without affecting cell morphology and cell number in the confluent 3T3-L1 fibroblasts and RGM-1 cells and also in 3T3-L1 adipocytes [84]. Chemical structure-activity relationship analysis revealed that some DIF derivatives, such as DIF-1 and DIF-1(3M), increased glucose uptake by two to three times in confluent 3T3-L1 fibroblasts in vitro (Figure 5) [71,84]. Since the glucose uptake-promoting activity of DIFs (Figure 5) is not necessarily correlated with their anti-proliferative activity (Figure 3), the mechanisms underlying the actions of DIFs in promoting glucose uptake should differ from those through which the compounds suppress tumor cell growth. 

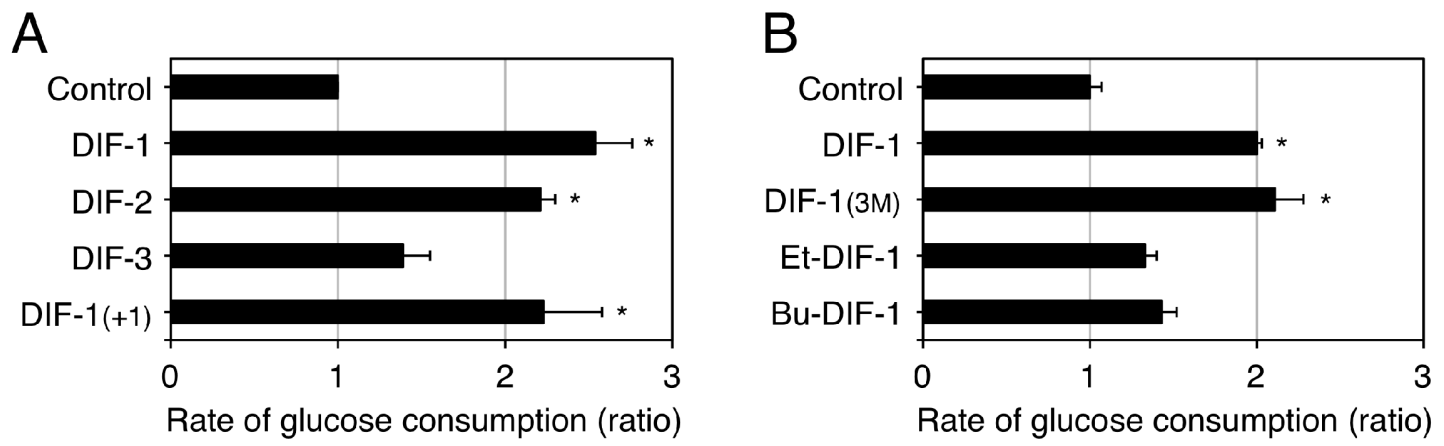

Figure 5. Effects of DIFs on glucose consumption (uptake) by confluent 3T3-L1 fibroblasts. Confluent 3T3-L1 fibroblasts were incubated at $37^{\circ} \mathrm{C}$ for at least $8 \mathrm{~h}$ in the presence of $0.2 \% \mathrm{EtOH}$ (vehicle; Control) or $20 \mu \mathrm{M}$ of one of the DIF derivatives. The glucose concentration in each incubation medium was measured and the approximate rate of glucose consumption was calculated relative to that in the Control medium; the rate of glucose consumption corresponds well with that of tritium-labeled 2-deoxy-glucose uptake promoted by DIF-1 [84]. The means and SD (bars) of three independent experiments (A) or triplicate experiments (B) are shown (adapted from Omata et al. [84] and Kubohara et al. [71], respectively). ${ }^{*} p<0.05$ versus Control (by $t$-test; two-tailed, unpaired).

The mechanism underlying the glucose uptake-promoting activities of DIF-1 and DIF-1(3M) has been partially elucidated (Figure 6); DIF-1 induces translocation of glucose transporter 1 (GLUT1) from intracellular vesicles to the plasma membrane via a PI3K-Akt-independent pathway, thereby promoting glucose uptake [84]. Note that DIF-1 (like insulin in 3T3-L1 adipocytes) was found to activate the PI3K-Akt pathway in all of the cell lines tested [84]. However, since DIF-1 promotes glucose uptake even in the presence of the PI3K inhibitors wortmannin and LY294002 in 3T3-L1 fibroblasts and 3T3-L1 adipocytes [84], the glucose uptake-promoting effect of DIF-1 is likely PI3K-Akt-independent. Also, DIF-1 and DIF-1(3M) disturb mitochondrial activity, possibly by acting as uncouplers and promote cellular glucose metabolism in vitro [77,85]. During analysis of the antitumor activity of DIF-3, Dubois et al. [69] found that DIF-3 at $20 \mu \mathrm{M}$ induces a loss of mitochondrial membrane potential, possibly by acting as an uncoupler and decreases cellular ATP levels in K562 leukemia cells. However, the glucose uptake-promoting activity of DIF-3 is considerably lower than those of DIF-1 and DIF-1(3M) in 3T3-L1 fibroblasts (Figure 5) and neither DIF-1 nor DIF-1(3M) at $20 \mu \mathrm{M}$ significantly affects cellular ATP levels in 3T3-L1 fibroblasts [85]; our group is currently examining the mechanism underlying DIF-induced translocation of GLUT1.

In vivo analyses have shown that intraperitoneal injection of DIF-3(3M) lowers blood glucose levels (after a meal) in KK-Ay diabetic mice [71] and that oral administration of DIF-1 lowers blood glucose levels in streptozotocin-induced diabetic rats without any apparent adverse effects [85]. These results suggest that DIF-1 and its derivatives may have therapeutic potential for the treatment of obesity and diabetes-especially of insulin-resistant diabetes. 


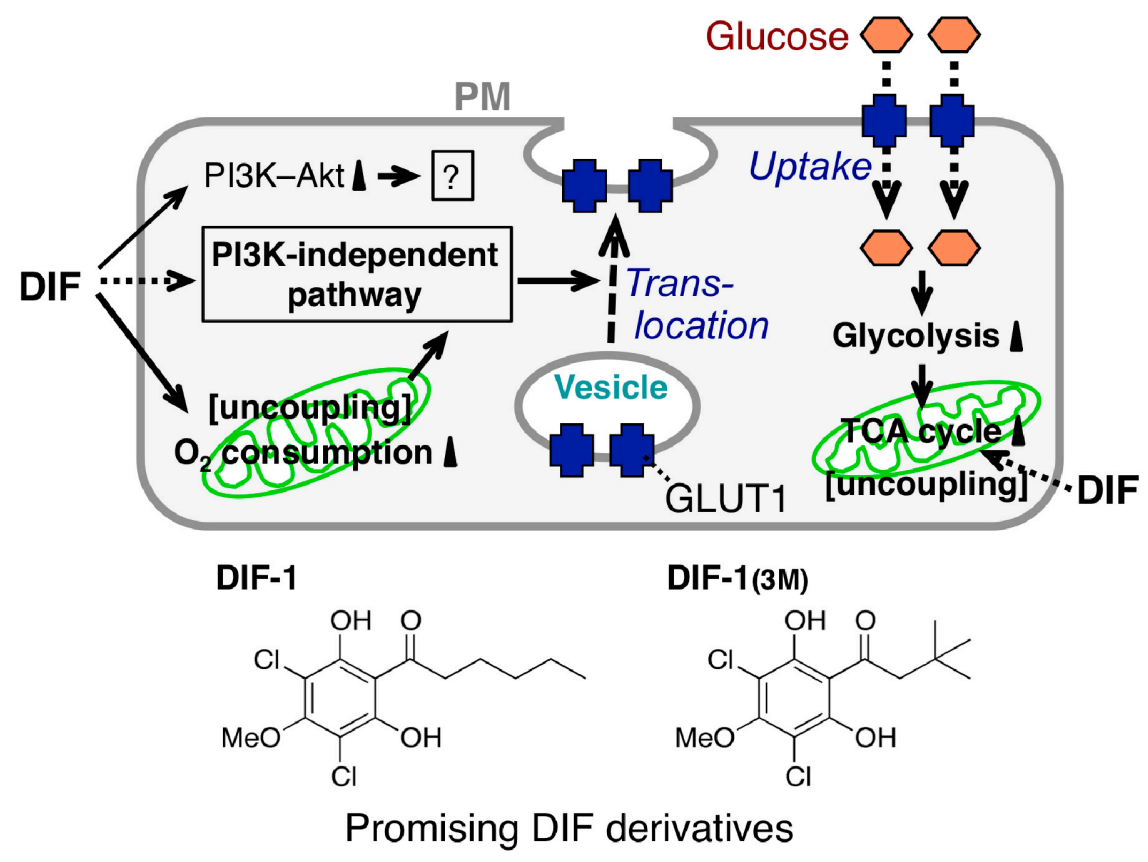

Figure 6. Proposed scheme for the glucose uptake-promoting effect of DIFs. Stimulation with a DIF induces glucose transporter 1 (GLUT1) translocation from intracellular vesicles to the plasma membrane (PM) via a PI3K-Akt-independent pathway, resulting in the promotion of glucose uptake by confluent mammalian cells [84]; the DIFs activate PI3K and Akt but this is not related to the DIF glucose uptake-promoting activity [84]. The DIFs also function as mitochondrial uncouplers, promoting oxygen consumption [77] and glucose metabolism (glycolysis and subsequent degradation in the tricarboxylic acid (TCA) cycle) [85] by mitochondria; this further increases GLUT1 translocation and promotes glucose uptake into the cells. Chemical structure-activity relationship analysis revealed that DIF-1 and DIF-1(3M) are promising lead compounds for the development of anti-diabetes and anti-obesity drugs [71,84,85].

\subsection{Other Biological Activities of DIFs}

\subsubsection{Differentiation-Inducing and -Promoting Activities}

As already mentioned, DIFs 1 and 3 at 10-30 $\mu \mathrm{M}$ dose-dependently induce cell differentiation in vitro in murine (B8) and human (K562) leukemia cells [61,64]. Also, DIF-1 at low concentrations $(1-5 \mu \mathrm{M})$ dose-dependently promotes retinoic acid-induced granulocyte differentiation in human HL-60 leukemia cells in vitro but it does not affect vitamin D-induced monocyte differentiation in HL-60 cells [63]. In addition, DIF-1 at $30 \mu \mathrm{M}$ induces re-differentiation of de-differentiated vascular smooth muscle cells (non-transformed cells) isolated from human umbilical arteries in vitro [70]. Dimethyl sulfoxide at $1 \%(v / v)$ induces cardiomyocyte differentiation in vitro in P19CL6 embryonic carcinoma cells and the activity of dimethyl sulfoxide is promoted in the presence of Br-DIF-1, a chlorine-to-bromine substituted derivative of DIF-1, at 1-3 $\mu \mathrm{M}$ [86]. In contrast, DIF-1 at 5-30 $\mu \mathrm{M}$ suppresses osteoblast differentiation markers in human osteosarcoma SaOS-2 cells in vitro [87]. Together, these results suggest that DIFs could be useful as differentiation-inducing (or promoting) factors for obtaining various types of objective cells from embryonic or induced pluripotent stem (iPS) cells and as lead compounds for the development of anti-cancer chemotherapies.

\subsubsection{Anti-Meiotic Activity}

Xenopus oocytes are a good model for investigating the mechanisms of meiosis and the associated signal transduction system. Maturation of Xenopus oocytes can be induced in vitro with progesterone, which subsequently induces germinal vehicle breakdown. DIF-1 at 10-40 $\mu \mathrm{M}$ dose-dependently 
suppresses progesterone-induced germinal vehicle breakdown in Xenopus oocytes in vitro, at least in part, by inhibiting a mitogen-activated protein kinase cascade [88].

\subsubsection{Immunomodulatory Activities in Jurkat T Cells}

Since DIFs 1 and 3 and their derivatives have been shown to exhibit multiple biological activities in D. discoideum, Xenopus oocytes and mammalian cells, we hypothesized that DIF derivatives may have additional biological activities in other mammalian and eukaryotic cells.

We then investigated the effects of DIFs 1 and 3 and their derivatives on interleukin-2 (IL-2) production in vitro in human Jurkat $\mathrm{T}$ cells, a model cell line suitable for the study of $\mathrm{T}$ lymphocytes $[89,90]$. In Jurkat $\mathrm{T}$ cells, IL-2 production can be induced in vitro by stimulation with mitogens such as concanavalin A (ConA) and ConA-induced IL-2 production can be suppressed with the immunosuppressive drug cyclosporin A (CsA) (Figure 7). Our group found that some DIF derivatives, including TH-DIF-1, TM-DIF-1 and Bu-DIF-3, at low doses (e.g., $5 \mu \mathrm{M}$ ) significantly suppressed ConA-induced IL-2 production, whereas other DIF derivatives, including DIF- $1(+1)$ and DIF-3(3M), significantly promoted ConA-induced IL-2 production in Jurkat T cells, with little effect on cell viability (Figure 7) $[89,90]$. Since IL-2 production in T cells is an index of immune system activity in vivo, these results suggest that DIF derivatives could be developed as novel immunosuppressive (and anti-inflammatory) or immunopromotive drugs.

A

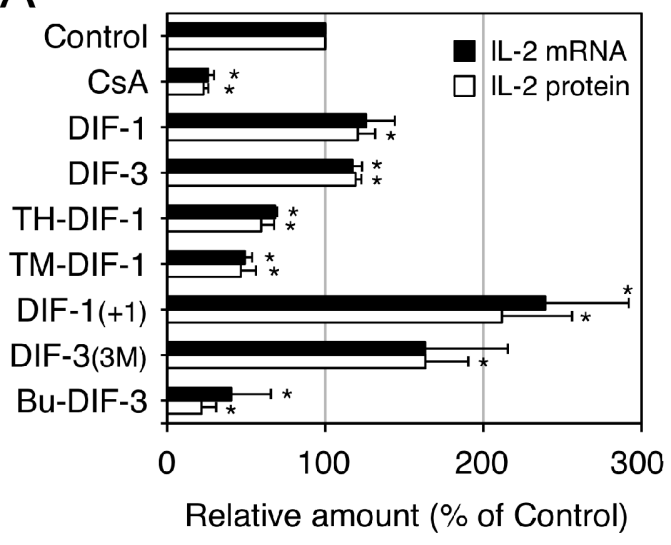

B

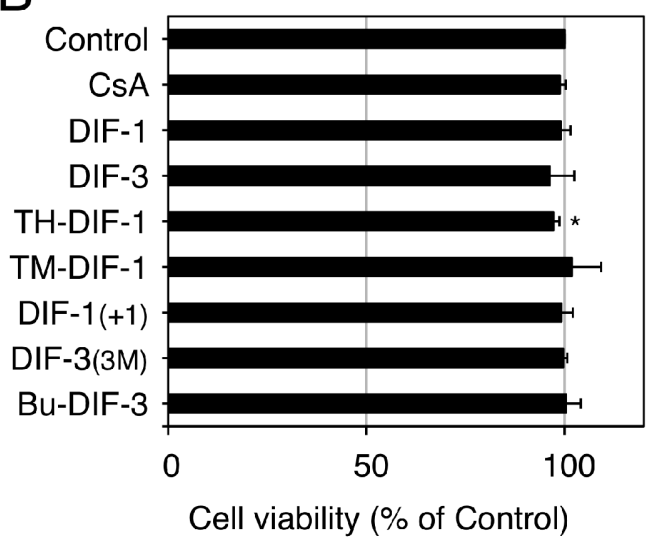

Figure 7. Effects of DIFs on ConA-induced IL-2 production in human Jurkat T cells. Jurkat T cells were pre-incubated at $37^{\circ} \mathrm{C}$ for $0.5 \mathrm{~h}$ in the presence of $0.1 \% \mathrm{EtOH}$ (vehicle; Control), $1 \mu \mathrm{M}$ cyclosporin A (CsA), or $5 \mu \mathrm{M}$ of one of the DIF derivatives. After the addition of ConA (as a mitogen), the cells were further incubated at $37^{\circ} \mathrm{C}$ for $3 \mathrm{~h}$ and assayed for IL-2 mRNA expression (A), whereas another set of cells were incubated for $12 \mathrm{~h}(\mathbf{A}, \mathbf{B})$ and assayed for IL-2 protein secretion (A) and for viability by using an MTT assay (B). The means and SD (bars) of three independent experiments are shown (adapted from Takahashi et al. [89]). ${ }^{*} p<0.05$ versus Control (by $t$-test; two-tailed, unpaired). ConA-induced IL-2 production was significantly suppressed by the known immunosuppressive drug, CsA and by TH-DIF-1, TM-DIF-1 and Bu-DIF-3 but it was significantly promoted by DIF-1(+1) and DIF-3(3M); cell viability at $12 \mathrm{~h}$ was not affected by any of the compounds, except for TH-DIF-1.

\subsubsection{Anti-Trypanosoma Activity}

Trypanosoma cruzi is the protozoan parasite that causes Chagas disease (human American trypanosomiasis). Despite the large number of deaths each year $(>15,000)[91]$, therapeutic options for acute cases are limited (e.g., benznidazole and nifurtimox) $[92,93]$ and there is no effective therapy for chronic cases.

To assess the pharmacological potential of DIFs 1 and 3 and their derivatives for the development of anti-T. cruzi drugs, our group examined the effects of these compounds on the infection rate and growth of T. cruzi in an in vitro assay system utilizing human fibrosarcoma HT1080 cells as host 
cells [94]. We found that DIF-3 derivatives such as DIF-3(+1) and Bu-DIF-3 at $10 \mu \mathrm{M}$ possessed strong anti-T. cruzi activities in vitro (Figure 8) and that intraperitoneally administered Bu-DIF-3 suppressed the increase in blood T. cruzi concentration in mice [94]. Interestingly, we also found that the DIF-3 derivatives that had strong anti-T. cruzi activity (Figure 8) also had strong anti-proliferative activity in tumor cells (Figure 3), suggesting that the activities of these derivatives in the two cell types may have similar underlying mechanisms.
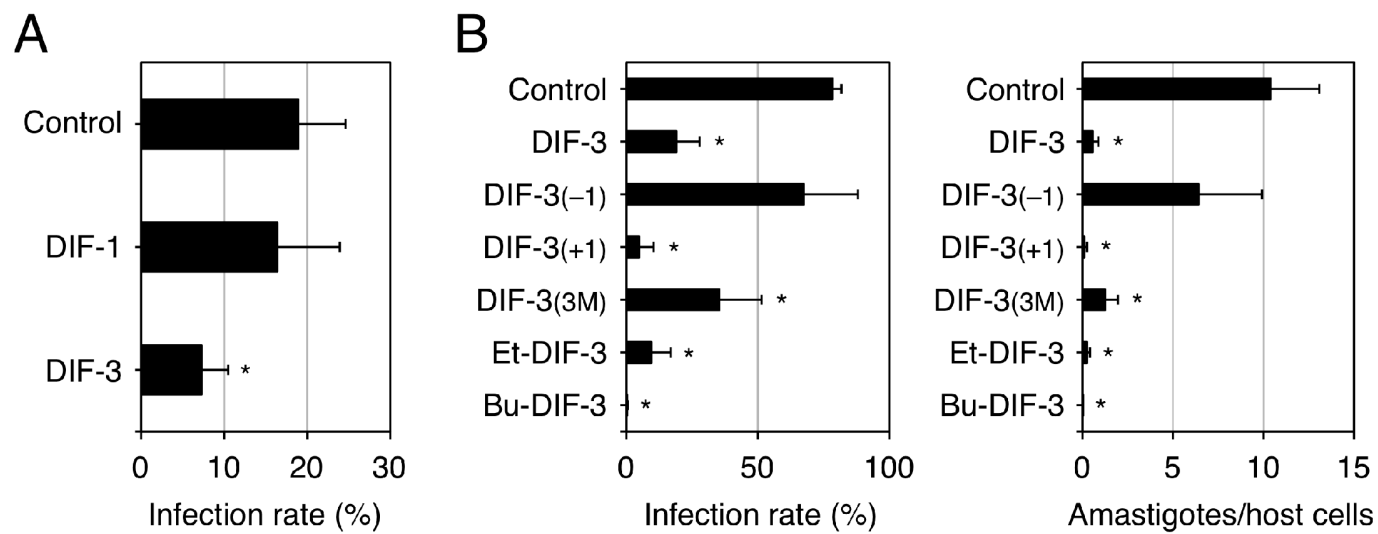

Figure 8. Effects of DIFs on the infection and growth of Trypanosoma cruzi in HT1080 cells. Trypanosoma cruzi (A: $1 \times 10^{5}$ cells/well, B: $5 \times 10^{6}$ cells/well) were incubated at $37^{\circ} \mathrm{C}$ for 3 days in vitro with human fibrosarcoma HT1080 cells (host cells) in the presence of $0.1 \% \mathrm{EtOH}$ (vehicle: Control) or $10 \mu \mathrm{M}$ of one of the DIF derivatives. Then, the infection rate (parasite-infected HT1080 cells/total HT1080 cells) $(\mathbf{A}, \mathbf{B})$ and the number of amastigotes (intracellular form of T. cruzi) in the HT1080 cells (B) were assessed microscopically [94]. The means and SD (bars) of three independent experiments are shown (adapted from Nakajima-Shimada et al. [94]). ${ }^{*} p<0.05$ versus Control (by $t$-test; two-tailed, unpaired). DIF-3 and some of its derivatives strongly suppressed T. cruzi infection and growth in the host cells.

\subsubsection{Anti- $\beta$-Amyloid Activity}

Alzheimer's disease is a form of dementia that is broadly characterized by memory loss and cognitive deterioration. During the progression of Alzheimer's disease, extracellular plaques of $\beta$-amyloid and neurofibrillary tangles form in specific regions of the brain. Since $\beta$-amyloid is produced physiologically from amyloid- $\beta$ protein precursor (APP) by most cells but particularly by neurons, it is thought that abnormal processing of APP in neurons results in the abnormal $\beta$-amyloid formation that characterizes Alzheimer's disease $[95,96]$.

Myre et al. [97] have shown that DIF-1 at $30 \mu \mathrm{M}$ reduces amyloidogenic processing of APP in CHO-7W cells stably expressing human APP in vitro; this suggests that DIF-1 could be a novel anti- $\beta$-amyloid drug. However, since DIF- 1 at $10-40 \mu \mathrm{M}$ is toxic to rat cortical neurons in primary culture in vitro [98], clinical use of DIF-1 would likely have adverse effects associated with the cortical neurons. Further investigation into the effects of the other DIF derivatives on APP processing and neuronal functions is warranted. However, for now, DIF-1 is a promising lead compound for the development of anti- $\beta$-amyloid and thus anti-Alzheimer's disease, drugs.

\subsubsection{Conclusions on the Activities of DIFs}

Figure 9 summarizes the physiological functions of DIF-1 and DIF-2 in D. discoideum and the biological activities of DIF derivatives in other organisms. Considering that DIFs possess a range of biological activities in various eukaryotic cells, the DIFs and their derivatives likely have some undiscovered biological and pharmacological activities. Why DIFs possess such a range of biological activities is unknown; however, elucidation of the mechanisms underlying these activities-especially identification of the target molecules-will help in answering this question. Since DIFs possess various biological activities, there would be multiple target molecules of the DIFs; some candidate 
targets of DIFs that may be involved in the functions of DIFs have been reported (Table 1). Direct inhibition of PDE1 and PAK1 by DIFs may cause antitumor effects [74,76], whereas uncoupling of mitochondrial activity by DIFs may cause antitumor effects and/or promote glucose consumption in mammalian cells [72,77,85]. Matsuda et al. [99] have reported that DIF-1 but not DIF-3, directly inhibits mitochondrial malate dehydrogenase (mMDH), which may affect glucose consumption.

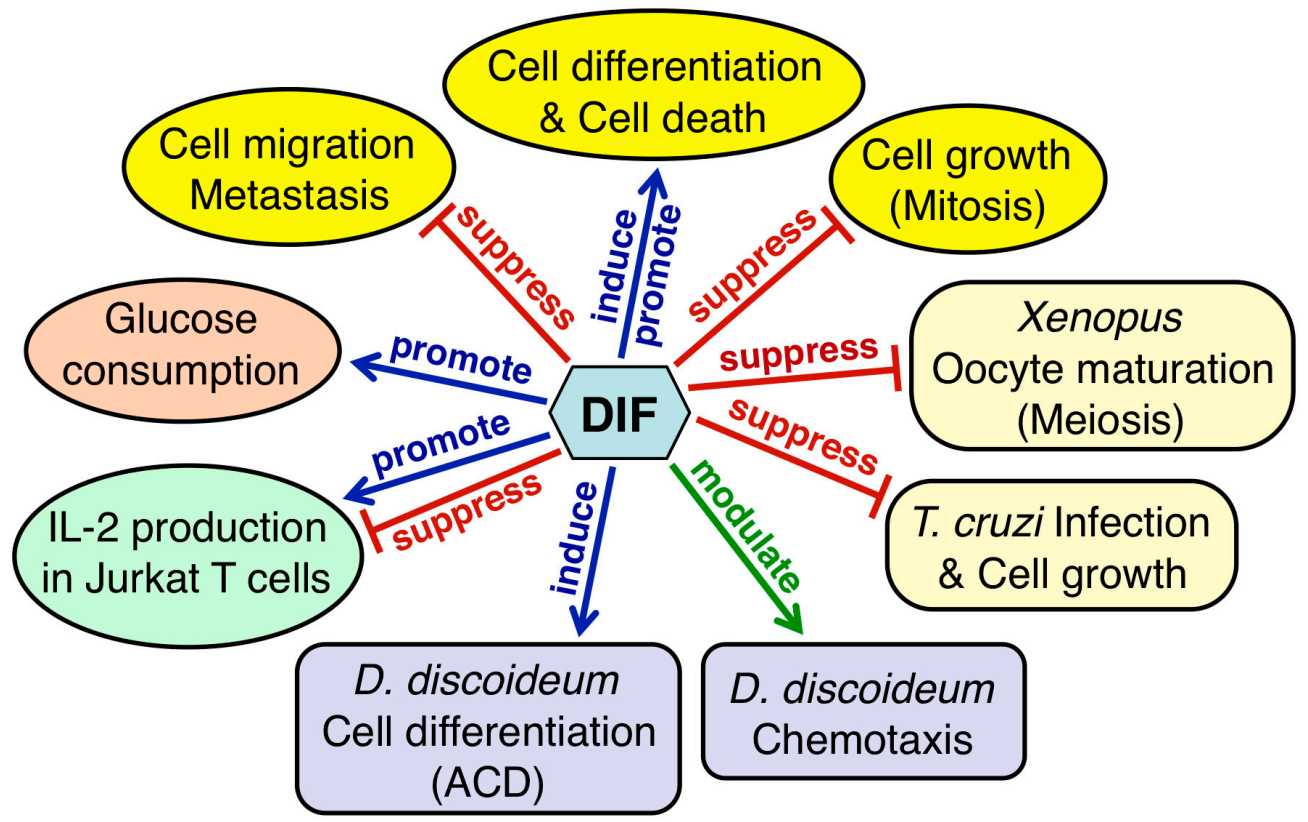

Figure 9. Summary of the physiological functions of DIFs 1 and 2 in Dictyostelium discoideum and the biological activities of DIF derivatives in other organisms. DIFs 1 and 2 function as inducers of stalk-cell differentiation (autophagic cell death: ACD) and as modulators of chemotactic cell movement in D. discoideum (purple rectangles). DIF derivatives have various biological activities in mammalian cells (yellow, orange and green ellipses) and in Xenopus oocytes and Trypanosoma cruzi (pale yellow rectangles).

Table 1. Targets of DIFs found in mammalian cells.

\begin{tabular}{cccc}
\hline DIF Species Examined & Target of DIF & Biological Activities & Reference \\
\hline DIF-1, DIF-3 & PDE1 & Direct inhibition of PDE1 activity & {$[76]$} \\
DIF-1 & mMDH & Direct inhibition of mMDH activity & {$[100]$} \\
DIF-1, DIF-3, \& their derivatives & Mitochondria & Uncoupling of mitochondrial activity & {$[72,77]$} \\
DIF-3 derivatives (e.g., DIF-3(+1)) & PAK1 & Direct inhibition of PAK1 activity & {$[74]$} \\
\hline
\end{tabular}

The data obtained to date strongly suggest that by modifying the side chains of the reported DIF derivatives we may be able to obtain compounds that have specific biological or pharmacological activities and that these compounds will be useful lead compounds for the development of anti-cancer, anti-obesity/diabetes, anti-T. cruzi and immunomodulatory agents.

The fact that DIF-like molecules such as DIFs 1-3 and DA (Figure 2) are produced by species in different kingdoms suggests that various DIF-like molecules are produced by all of the organisms belonging to Amoebozoa and Mycota. Furthermore, DA, which was found as an anti-tumor agent, may have a physiologic function, such as the induction of cell differentiation, in the organism in which it was first identified, namely Chaetomium. 


\section{Novel Biologically Active Compounds Found in Cellular Slime Molds}

\subsection{Dictyopyrones}

While searching for biologically active secondary metabolites, Takaya et al. [100] isolated two novel $\alpha$-pyronoids, dictyopyrones A and B (Figure 10A), from methanol extracts of the fruiting bodies of D. discoideum and D. rhizoposium and another $\alpha$-pyronoid, dictyopyrone C (Figure 10A), from methanol extracts of the fruiting bodies of $D$. longosporum. Later, dictyopyrone A was also isolated from D. longosporum, dictyopyrone B was isolated from D. magnum and D. mucoroides and a new $\alpha$-pyronoid, dictyopyrone D, was isolated from D. magnum (Figure 10A) [101]. Furthermore, Kikuchi et al. [29] isolated dihydrodictyopyrones A and C from D. firmibasis (Figure 10A). Although there are several known $\alpha$-pyronoids with a hydroxyl group at the C-4 position, the dictyopyrones bear a unique $\alpha$-pyrone moiety (3-acyl-4,6-dialkyl- $\alpha$-pyrone ring) with a side chain at the C-3 position. This indicates that Dictyostelium cellular molds possess one or more unique biosynthetic pathways, providing further evidence that they are potentially valuable sources of lead compounds.

Recently, the production of dictyobispyrones B and E, alongside the production of dictyopyrones B and E, was induced in D. giganteum in the presence of zinc (II) ion (Figure 10A) [102]. The dictyobispyrones contain an $\alpha, \alpha$-bispyrone skeleton that can be biosynthesized from two distinct polyketide chains and therefore they could be biosynthetic precursors for the production of dictyopyrones through hydration and decarboxylation reactions.

By using chemically synthesized dictyopyrones [100,101], we have shown that dictyoypones A-D at micromolar levels promote morphogenesis of D. discoideum $[100,101]$ and that dictyopyrones $\mathrm{A}$ and $\mathrm{B}$ at micromolar levels inhibit spore formation and promote stalk-cell formation in vitro in D. discoideum [103]. Also, we have reported that dictyopyrones and their derivatives suppress cell growth in human leukemia K562 cells in vitro [101].

A<smiles>[R]C(=O)C1=C(C)C[C@@H](C)OC1=O</smiles>

Dictyopyrone

$A: R=$

$B: R=>C_{C}^{14} H_{3}$

$\mathrm{C}: \mathrm{R}=\curvearrowright \sim \mathrm{CH}_{3}$

$D: R=\curvearrowright C_{B}$

$E: R=>C_{15}$

$\mathrm{C}_{\mathrm{O}}^{\mathrm{C}: \mathrm{R}=}$

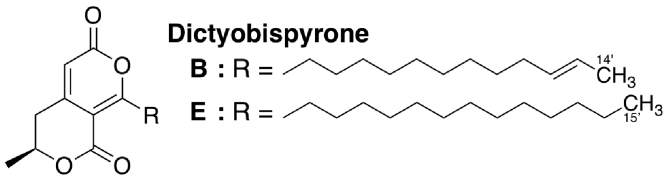

B Furanodictine A
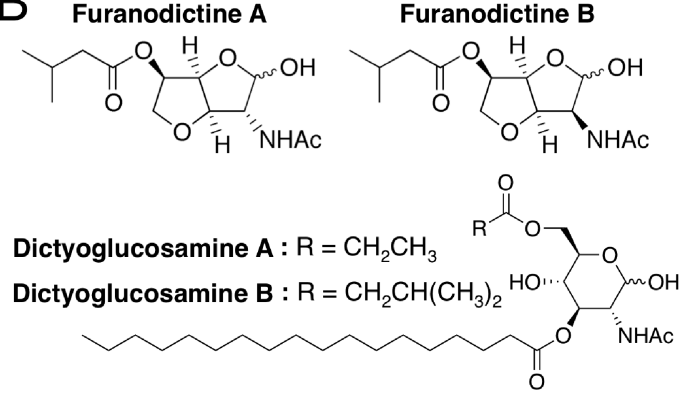

C Brefelamide<smiles>Nc1c(Oc2ccc(O)cc2)cccc1C(=O)CCNC(=O)c1ccc(O)cc1</smiles>

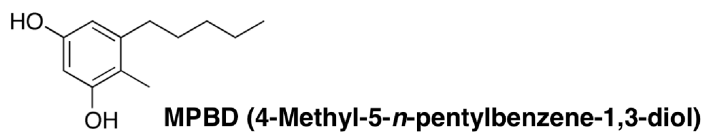

Monochasiol<smiles>[R]c1cc(O)c(Cl)c(O)c1</smiles>

$\mathrm{OH}$

$\mathrm{C}: \mathrm{R}=$

$\mathbf{D}: \mathrm{R}=\overbrace{\mathrm{B}^{\prime}}$

$\mathrm{E}: \mathrm{R}=$

$F: R=$

$G: R=$

$\mathbf{H}: \mathbf{R}=$

D

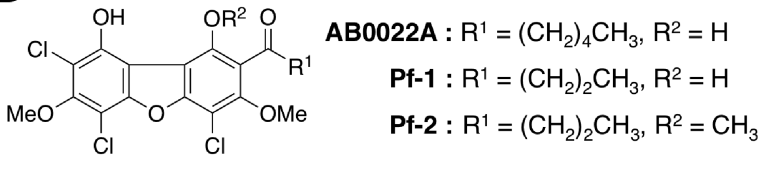

Figure 10. Chemical structures of secondary metabolites isolated from cellular slime molds. (A) dictyopyrones; (B) furanodictines; (C) Brefelamide, MPBD and Monochasiols; (D) AB0022A, Pf-1 and Pf-2. 


\subsection{Amino Sugar Derivatives: Furanodictines and Dictyoglucosamines}

Kikuchi et al. [25] isolated two novel amino sugar derivatives, furanodictines A and B (Figure 10B), from methanol extracts of the fruiting bodies of $D$. discoideum. These compounds are derivatives of $N$-acetylglucosamine and $N$-acetylmannosamine, respectively and were the first 3,6-anhydrosugars isolated from a natural product. The unique structures of the furanodictines are intriguing and four research groups have reported four different synthetic pathways [25,104-106].

Two other amino sugar derivatives, dictyoglucosamines A and B (Figure 10B), were isolated from methanol extracts of D. purpureum and D. discoideum, respectively [26]. These compounds are characteristic in that the amino sugar is connected directly to the fatty acid.

The biological activities of these amino sugar derivatives were investigated and it was found that (1) furanodictine B but not furanodictine $\mathrm{A}$, at $20 \mu \mathrm{M}$ increases neurite formation in vitro in rat pheochromocytoma PC-12 cells, which are a model of neuronal differentiation; (2) furanodictine A and furanodictine $\mathrm{B}$ at $0.5-5 \mu \mathrm{M}$ dose-dependently promote neurite formation in the presence of nerve growth factor (NGF) [25]; and (3) dictyoglucosamine A and dictyoglucosamine B at 1-10 $\mu \mathrm{M}$ dose-dependently induce neurite formation in PC-12 cells [26]. Thus, these amino sugar derivatives may be good lead compounds for the development of novel nerve-rejuvenation drugs for treating neurodegenerative diseases such as Alzheimer's disease.

\subsection{Brefelamide}

Brefelamide (Figure 10C) is an aromatic amide that was isolated from methanol extracts of the fruiting bodies of D. brefeldianum and D. giganteum [27,107]. The 2-amino-3-hydroxy- $\beta$-aminopropiophenone moiety of brefelamide, which could be biosynthesized from tryptophan, is a rare structure in natural compounds.

Brefelamide at 1-100 $\mu \mathrm{M}$ dose-dependently suppresses cell growth in human astrocytoma $1321 \mathrm{~N} 1$ cells in vitro through reduced glial cell line-derived neurotrophic factor (GDNF) receptor expression, reduced GDNF secretion and reduced phosphorylation of Erk, Akt and c-Jun N-terminal kinases [27,107]. Also, brefelamide at 12.5-50 $\mu \mathrm{M}$ suppresses the growth of and invasion by, A562 lung cancer cells in vitro, at least in part by inhibiting osteopontin expression [108]. In addition, brefelamide and its $O$-methyl derivative suppress osteopontin production in dengue serotype 3 virus-infected THP-1 cells, indicating that these compounds can prevent exacerbation of the illness to dengue hemorrhagic fever or dengue shock syndrome [109].

\section{4. $M P B D$}

MPBD (4-methyl-5-n-pentylbenzene-1,3-diol) (Figure 10C) is a polyketide that was isolated independently by two research groups as a secondary metabolite from D. mucoroides [28] and as an endogenous differentiation-inducing factor from $D$. discoideum [110]. Although the physiologic functions of MPBD in these organisms are unclear, MPBD at low nanomolar concentrations promotes both stalk-cell differentiation (albeit slightly) and spore differentiation in $D$. discoideum under some in vitro culture conditions [28,110]. At 20-80 $\mu \mathrm{M}, \mathrm{MPBD}$ dose-dependently suppresses the growth of human leukemia K562 and HL-60 cells in vitro [28]. In addition, MPBD and its synthetic derivatives possess antimicrobial activities against Escherichia coli and Bacillus subtilis [111].

\subsection{Monochasiols}

Monochasiols A-H (Figure 10C) are chlorinated alkylresorcinols (and also polyketides) isolated from the fruiting bodies of D. monochasioides [33]. Although elucidation of their biological activities is ongoing, it has been shown that monochasiol A at 5-20 $\mu \mathrm{M}$ suppresses ConA-induced IL-2 production in Jurkat T cells without affecting cell viability [33]. 
Since the monochasiols can potentially be biogenetically synthesized by combining biosynthetic enzymes related to the principal polyketides DIF-1 and MPBD produced by D. discoideum, Dictyostelium cellular slime molds may produce a diverse range of monochasiol-based secondary metabolites.

\subsection{Dibenzofurans: $A B 0022 A, P f-1$ and $P f-2$}

AB0022A (Figure 10D) is an antimicrobial agent that is produced by D. purpureum and inhibits the growth of several Gram-positive but not Gram-negative, bacteria (minimal inhibitory concentration, 0.39-50 $\mu \mathrm{g} / \mathrm{mL} ; 0.85-109 \mu \mathrm{M}$ ) [112]. Recently, two other chlorinated dibenzofurans, Pf-1 and Pf-2 (Figure 10D), were isolated from the fruiting bodies of Polysphondylium filamentosum [32]. Although the antimicrobial activities of Pf- 1 and Pf-2 are unknown, Pf- 1 at $0.1-2 \mu \mathrm{M}$, like DIF-1, dose-dependently induces stalk-cell formation in D. discoideum in vitro, whereas AB0022A and Pf- 2 at up to $2 \mu \mathrm{M}$ do not [32]. AB0022A and Pf-1 but not Pf-2, at low micromolar concentrations suppress the growth of human leukemia K562 and HL-60 cells in vitro [32]. These findings suggest that, like DIF derivatives, the chlorinated dibenzofurans and their derivatives may possess multiple biological activities and that Polysphondylium species are also promising sources of lead compounds for natural product chemistry.

\subsection{Prenylated and Geranylated Aromatic Compounds: Pt-1-5 and Ppc-1}

The novel aromatic compounds Pt-1-5 and Ppc-1 (Figure 11A) were isolated from Polysphondylium tenuissimum and P. pseudo-candidum, respectively [30]. These compounds bear prenyl or geranyl groups. Pt-4 and Pt-5, which also each bear a butanoyl group, can be biosynthesized via the analogous polyketide DIF-1 (Figure 2A), which contains a hexanoyl group. The difference in length of the acyl groups may account for the chemotaxonomic differences between the genera Dictyostelium and Polysphondylium.

Pt-1, Pt-5 and Ppc-1 at $15 \mu \mathrm{M}$ suppress the growth of human leukemia K562 cells in vitro and Ppc-1 suppresses the growth of HeLa cells in vitro [30]. Ppc-1 at $20 \mu \mathrm{M}$, like DIF-1, promotes glucose consumption by 3T3-1 cells in vitro [30] and intraperitoneally administered Ppc-1 induces weight loss in mice, possibly by uncoupling mitochondrial function [113]. Furthermore, Ppc-1 and its derivative, PQA-18 (Figure 11A), suppress IL-2 production in Jurkat T cells in vitro [114]. Another Ppc-1 derivative, PQA-11 (Figure 11A), has potent neuroprotective activities in vitro and in vivo, possibly via the inhibition of mitogen-activated protein kinase kinase 4 (MKK4) [115].

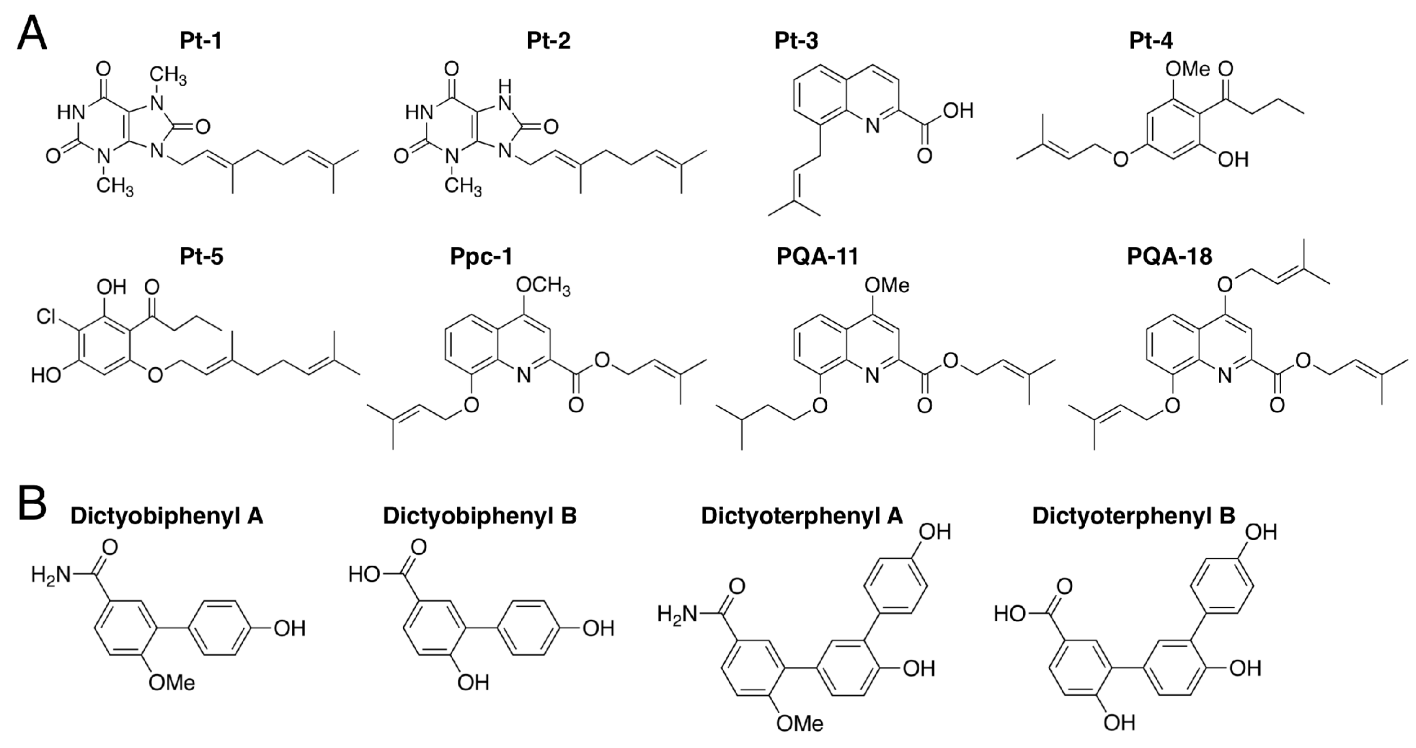

Figure 11. (A) Chemical structures of Pt-1-5 and Ppc-1 isolated from Polysphondylim tenuissimum and P. pseudo-candidum and two derivatives of Ppc-1, PQA-11 and PQA-18; (B) Chemical structures of dictyobiphenyls A and B and dictyoterphenyls A and B, isolated from Dictyostelium polycephalum. 


\subsection{Dictyobiphenyls and Dictyoterphenyls}

Dictyobiphenyls A and B and dictyoterphenyls A and B, are novel aromatic compounds (Figure 11B) that were isolated from the fruiting bodies of D. polycephalum [13]; note that dictyoterphenyl A was the first nitrogen-containing natural $m$-terphenyl isolated. Dictyoterphenyl A at 1-10 $\mu \mathrm{M}$ can suppress the growth of several cancer cell lines in vitro, such as the K562, HeLa and LM8 cell lines [13].

\section{Conclusions}

In this review, we have shown that DIFs 1 and 3 and their derivatives possess multiple biological activities in a variety of eukaryotic cells and the data suggest that they will be useful lead compounds for the development of anti-cancer, anti-obesity/diabetes, anti-T. cruzi and immunomodulatory agents. Moreover, our group has isolated various novel and unique compounds from Dictyostelium and Polysphondylium cellular slime molds and we have shown that some of these compounds have biological activities in mammalian cells in vitro and in vivo, which are summarized in Table 2. Together, the data strongly suggests that cellular slime molds are excellent sources of lead compounds for natural product chemistry and the development of next-generation drugs.

Table 2. Origins and biological activities of the compounds that were found in cellular slime molds.

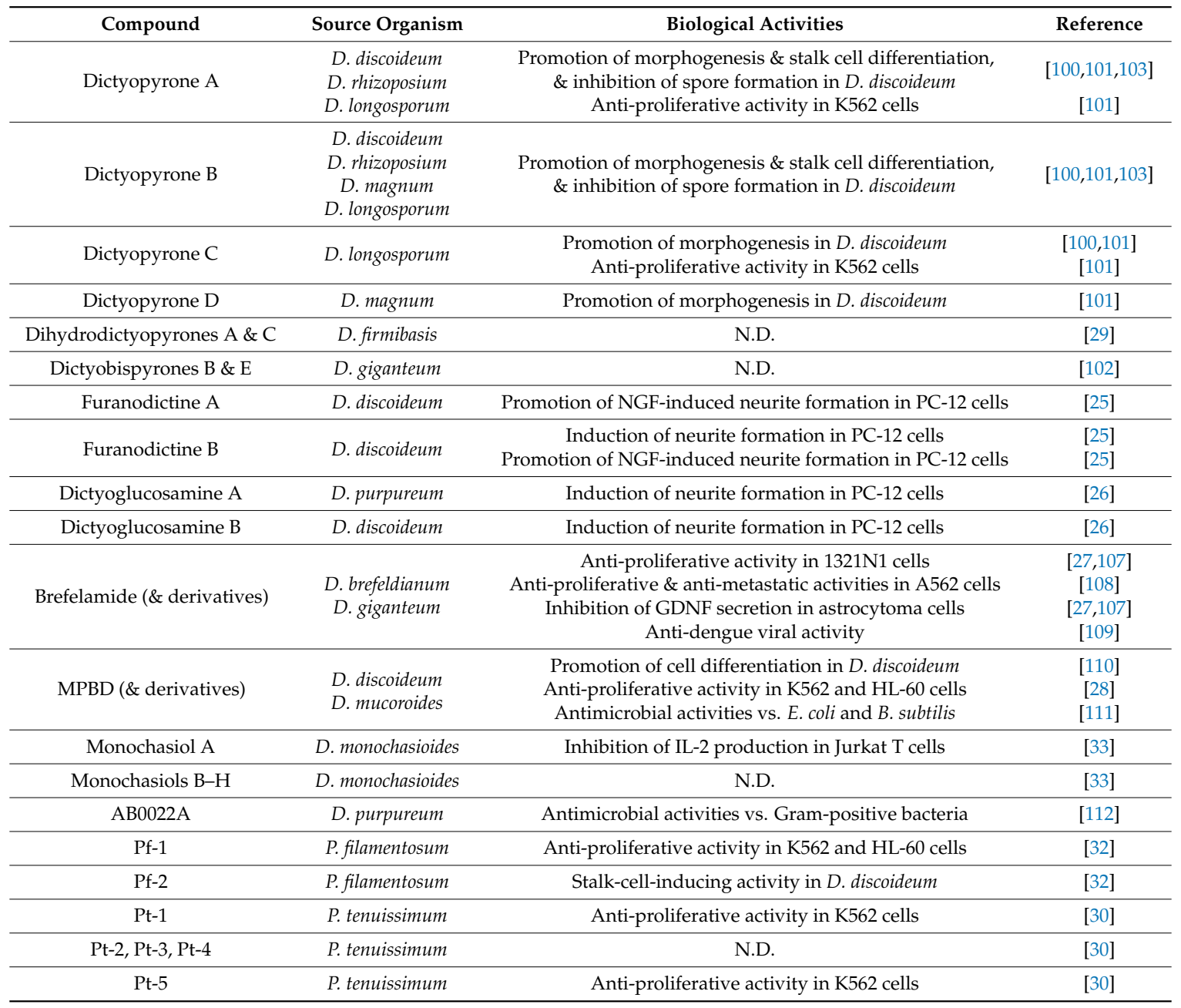


Table 2. Cont.

\begin{tabular}{cccc}
\hline Compound & Source Organism & Biological Activities & Reference \\
\hline Ppc-1 (\& derivatives) & P. pseudo-candidum & $\begin{array}{c}\text { Anti-proliferative activity in K562 and HeLa cells } \\
\text { Promotion of glucose consumption in 3T3-L1 cells } \\
\text { \& mitochondrial uncoupling }\end{array}$ & $\begin{array}{c}\text { [30] } \\
\text { Inhibition of IL-2 production in Jurkat T cells }\end{array}$ \\
\hline [30,112] & Neuroprotective activities in vitro and in vivo & N.D. \\
\hline [114] & [115] & [31] \\
\hline Dictyobiphenyls A \& B & D. polycephalum & Anti-proliferative activity in K562, HeLa and LM8 cells & N.D. \\
\hline Dictyoterphenyl B & D. polycephalum & &
\end{tabular}

\section{Patents}

Patents related to our work on DIFs and other compounds:

Kubohara, Y.; Shibata, H. Agents that promote glucose metabolism and a method for screening anti-obesity and anti-diabetes drugs. Japanese Patent No. 4534039, 25 June 2010.

Kubohara, Y.; Shimada, J. Anti-Trypanosoma agents and drugs for trypanosomiases. Japanese Patent No. 5610433, 12 September 2014.

Kubohara, Y.; Murakami, M.; Takahashi, K.; Oshima, Y.; Kikuchi, H. Inhibitors of interleukin-2 production. Japanese Patent No. 5630751, 17 October 2014.

Kikuchi, H.; Oshima, Y.; Hattori, T.; Kubohara, Y.; Yamada, O.; Zhang, J.; Matsushita, Y.; Kida, S. Osteopontin production inhibitor with dictyopyrone or dihydrodictyopyrone derivatives as the active ingredient. Japanese Patent No. 5716140, 20 March 2015; Australian Patent No. 2013380489, 14 January 2016; Korean Patent No. 1593018, 2 February 2016; Canadian Patent No. 2896446, 28 June 2016; US Patent No. 9463188 B2, 11 October 2016; Chinese Patent No. ZL201380069437.4, 9 June 2017; EU Patent No. 2965758, 3 January 2018.

Honma, Y.; Suzuki, T.; Ogura, M; Oshima, Y.; Kikuchi, H. Prenyloxyquinoline carboxylic-acid derivative. Japanese Patent No. 6348845, 8 June 2018.

Funding: Our work was supported in part by JSPS KAKENHI (grant nos. 09680686, 15590123, 17590115, 19590136, 21590090, 24590110 and 15K07964 to YK; nos. 25350959 and 16H03279 to HK); Research for Promoting Technology Seeds (Nos. 05-018 and 05-021 to YK), Support to Increase the Value of Patents Held by Universities and Public Research Institutions, Accelerating Utilization of University IP Program (to YK) and Exploratory Research Type, Feasibility Study Stage, Adaptable and Seamless Technology Transfer Program through Target-Driven R\&D (A-STEP) (No. AS232Z00488G to YK) from the Japan Science and Technology Agency (JST); Platform Project for Supporting in Drug Discovery and Life Science Research (Basis for Supporting Innovative Drug Discovery and Life Science Research (BINDS)) from the Japan Agency for Medical Research and Development (AMED) (No. JP18am0101100 to HK); Kobayashi International Scholarship Foundation (HK); and grants from the Takeda Science Foundation (Y.K. and H.K., respectively).

Acknowledgments: We thank our colleagues for their efforts and support. We especially thank Yoshiteru Oshima (Tohoku University, Japan) for having taken command of several of the projects introduced in this review.

Conflicts of Interest: The authors declare no conflict of interest.

\section{References}

1. Clardy, J.; Fischbach, M.A.; Walsh, C.T. New antibiotics from bacterial natural products. Nat. Biotech. 2006, 24, 1541-1550. [CrossRef] [PubMed]

2. Challinor, V.L.; Bode, H.B. Biozctive natural products from novel microbial sources. Ann. N. Y. Acad. Sci. 2015, 1354, 82-97. [CrossRef] [PubMed]

3. Keller, N.P. Fungal secondary metabolism: Regulation, function and drug discovery. Nat. Rev. Microbiol. 2018, in press. [CrossRef] [PubMed]

4. Brown, E.D.; Wright, G.D. Antibacterial drug discovery in the resistance era. Nature 2016, 529, $336-343$. [CrossRef] [PubMed] 
5. Adl, S.M.; Simpson, A.G.; Farmer, M.A.; Andersen, R.A.; Anderson, O.R.; Barta, J.R.; Bowser, S.S.; Brugerolle, G.; Fensome, R.A.; Fredericq, S.; et al. The new higher level classification of eukaryotes with emphasis on the taxonomy of protists. J. Eukaryot. Microbiol. 2005, 52, 399-451. [CrossRef] [PubMed]

6. $\quad$ Eichinger, L.; Pachebat, J.A.; Glöckner, G.; Rajandream, M.A.; Sucgang, R.; Berriman, M.; Song, J.; Olsen, R.; Szafranski, K.; Xu, Q.; et al. The genome of the social amoeba Dictyostelium discoideum. Nature 2005, 435, $43-57$. [CrossRef]

7. Adl, S.M.; Simpson, A.G.; Lane, C.E.; Lukeš, J.; Bass, D.; Bowser, S.S.; Brown, M.W.; Burki, F.; Dunthorn, M.; Hampl, V.; et al. The revised classification of eukaryotes. J. Eukaryot. Microbiol. 2012, 59, 429-493. [CrossRef]

8. Raper, K.B. Dictyostelium discoideum, A new species of slime mold from decaying forest leaves. J. Agric. Res. 1935, 55, 289-316.

9. Newell, P.C. The development of the cellular slime mould Dictyostelium discoideum: A model system for the study of cellular differentiation. Essays Biochem. 1971, 7, 87-126.

10. Firtel, R.A.; Meili, R. Dictyostelium: A model for regulated cell movement during morphogenesis. Curr. Opin. Genet. Dev. 2000, 10, 421-427. [CrossRef]

11. Calvo-Garrido, J.; Carilla-Latorre, S.; Kubohara, Y.; Santos, N.; Mesquita, A.; Soldati, T.; Golstein, P.; Escalante, R. Autophagy in Dictyostelium: Genes and pathways, cell death and infection. Autophagy 2010, 6, 686-701. [CrossRef] [PubMed]

12. Loomis, W.F. Cell signaling during development of Dictyoslteium. Dev. Biol. 2014, 391, 1-16. [CrossRef] [PubMed]

13. Loomis, W.F. Genetic control of morphogenesis in Dictyostelium. Dev. Biol. 2015, 402, 146-161. [CrossRef] [PubMed]

14. Nichols, J.M.; Veltman, D.; Kay, R.R. Chemotaxis of a model organism: Progress with Dictyostelium. Curr. Opin. Cell Biol. 2015, 36, 7-12. [CrossRef]

15. Bretschneider, T.; Othmer, H.G.; Weijer, C.J. Progress and perspectives in signal transduction, actin dynamics and movement at the cell and tissue level: Lessons from Dictyostelium. Interface Focus 2016, 6, 20160047. [CrossRef]

16. Huber, R.J. Using the social amoeba Dictyostelium to study the functions of proteins linked to neuronal ceroid lipofuscinosis. J. Biomed. Sci. 2016, 23, 83. [CrossRef]

17. Mesquita, A.; Cardenal-Muñoz, E.; Dominguez, E.; Muñoz-Braceras, S.; Nuñez-Corcuera, B.; Phillips, B.A.; Tábara, L.C.; Xiong, Q.; Coria, R.; Eichinger, L.; et al. Autophagy in Dictyostelium: Mechanisms, regulation and disease in a simple biomedical model. Autophagy 2017, 13, 24-40. [CrossRef] [PubMed]

18. Stuelten, C.H.; Parent, C.A.; Montell, D.J. Cell motility in cancer invasion and metastasis: Insights from simple model organisms. Nat. Rev. Cancer 2018, 18, 296-312. [CrossRef]

19. Domínguez-Martín, E.; Hernández-Elvira, M.; Vincent, O.; Coria, R.; Escalante, R. Unfolding the Endoplasmic Reticulum of a Social Amoeba: Dictyostelium discoideum as a New Model for the Study of Endoplasmic Reticulum Stress. Cells 2018, 7, 56. [CrossRef]

20. Dannat, K.; Tillner, J.; Winckler, T.; Weiss, M.; Eger, K.; Dingermann, T. Effects of medicinal compounds on the differentiation of the eukaryotic microorganism dictyostelium discoideum: Can this model be used as a screening test for reproductive toxicity in humans? Pharmazie 2003, 58, 204-210.

21. Ludtmann, M.H.; Boeckeler, K.; Williams, R.S. Molecular pharmacology in a simple model system: Implicating MAP kinase and phosphoinositide signalling in bipolar disorder. Semin. Cell Dev. Biol. 2011, 22, 105-113. [CrossRef] [PubMed]

22. Walker, M.C.; Williams, R.S. New experimental therapies for status epilepticus in preclinical development. Epilepsy Behav. 2015, 49, 290-293. [CrossRef] [PubMed]

23. Rzepnikowska, W.; Flis, K.; Muñoz-Braceras, S.; Menezes, R.; Escalante, R.; Zoladek, T. Yeast and other lower eukaryotic organisms for studies of Vps13 proteins in health and disease. Traffic 2017, 18, 711-719. [CrossRef] [PubMed]

24. Swart, A.L.; Harrison, C.F.; Eichinger, L.; Steinert, M.; Hilbi, H. Acanthamoeba and Dictyostelium as cellular models for Legionella infection. Front. Cell. Infect. Microbiol. 2018, 8, 61. [CrossRef]

25. Kikuchi, H.; Saito, Y.; Komiya, J.; Takaya, Y.; Honma, S.; Nakahata, N.; Ito, A.; Oshima, Y. Furanodictine A and B: Amino sugar analogues produced by cellular slime mold Dictyostelium discoideum showing neuronal differentiation activity. J. Org. Chem. 2001, 66, 6982-6987. [CrossRef] 
26. Kikuchi, H.; Komiya, J.; Sito, Y.; Sekiya, J.; Honma, S.; Nakahata, N.; Oshima, Y. The isolation and synthesis of two novel $\mathrm{N}$-acetyl glucosamine derivatives from Dictyostelium cellular slime molds which exhibit neurite outgrowth activity. Tetrahedron Lett. 2002, 43, 1477-1480. [CrossRef]

27. Kikuchi, H.; Saito, Y.; Sekiya, J.; Okano, Y.; Saito, M.; Nakahata, H.; Kubohara, Y.; Oshima, Y. Isolation and synthesis of a new aromatic compound, brefelamide, from Dictyostelium cellular slime molds and its inhibitory effect on proliferation of astrocytoma cells. J. Org. Chem. 2005, 70, 8854-8858. [CrossRef]

28. Kikuchi, H.; Oshima, Y.; Ichimura, A.; Gokan, N.; Hasegawa, A.; Hosaka, K.; Kubohara, Y. Anti-leukemic activities of Dictyostelium secondary metabolites: A novel aromatic metabolite, 4-methyl-5-npentylbenzene-1,3-diol, isolated from Dictyostelium mucoroides suppresses cell growth in human leukemia K562 and HL-60 cells. Life Sci. 2006, 80, 160-165. [CrossRef]

29. Kikuchi, H.; Nakamura, K.; Kubohara, Y.; Gokan, N.; Hosaka, K.; Maeda, Y.; Oshima, Y. Dihydrodictyopyrone A and C: New members of dictyopyrone family isolated from Dictyostelium cellular slime molds. Tetrahedron Lett. 2007, 48, 5905-5909. [CrossRef]

30. Kikuchi, H.; Ishiko, S.; Nakamura, K.; Kubohara, Y.; Oshima, Y. Novel prenylated and geranylated aromatic compounds isolated from Polysphondylium cellular slime molds. Tetrahedron 2010, 66, 6000-6007. [CrossRef]

31. Kikuchi, H.; Matsuo, Y.; Katou, Y.; Kubohara, Y.; Oshima, Y. Isolation, synthesis and biological activity of biphenyl and m-terphenyl-type compounds from Dictyostelium cellular slime molds. Tetrahedron 2012, 68, 8884-8889. [CrossRef]

32. Kikuchi, H.; Kubohara, Y.; Nguyen, V.H.; Katou, Y.; Oshima, Y. Novel chlorinated dibenzofurans Isolated from the cellular slime mold, Polysphondylium filamentosum and their biological activities. Bioorg. Med. Chem. 2013, 21, 4628-4633. [CrossRef] [PubMed]

33. Kikuchi, H.; Ito, I.; Takahashi, K.; Ishigaki, H.; Iizumi, K.; Kubohara, Y.; Oshima, Y. Isolation, synthesis and biological activity of chlorinated alkylresorcinols from Dictyostelium cellular slime molds. J. Nat. Prod. 2017, 80, 2716-2722. [CrossRef] [PubMed]

34. Barnett, R.; Stallforth, P. Natural products form social amoebae. Biol. Chem. 2018, 24, 4202-4214.

35. Sucgang, R.; Kuo, A.; Tian, X.; Salerno, W.; Parikh, A.; Feasley, C.L.; Dalin, E.; Tu, H.; Huang, E.; Barry, K.; et al. Comparative genomics of the social amoebae Dictyostelium discoideum and Dictyostelium purpureum. Genome Biol. 2011, 12, R20. [CrossRef] [PubMed]

36. Morris, H.R.; Taylor, G.W.; Masento, M.S.; Jermyn, K.A.; Kay, R.R. Chemical structure of the morphogen differentiation inducing factor from Dictyostelium discoideum. Nature 1987, 328, 811-814. [CrossRef] [PubMed]

37. Morris, H.R.; Masento, M.S.; Taylor, G.W.; Jermyn, K.A.; Kay, R.R. Structure elucidation of two differentiation inducing factors (DIF-2 and DIF-3) from the cellular slime mould Dictyostelium discoideum. Biochem. J. 1988, 249, 903-906. [CrossRef] [PubMed]

38. Masento, M.S.; Morris, H.R.; Taylor, G.W.; Johnson, S.J.; Skapski, A.C.; Kay, R.R. Differentiation-inducing factor from the slime mould Dictyostelium discoideum and its analogues. Biochem. J. 1988, 256, 23-28. [CrossRef] [PubMed]

39. Kay, R.R.; Berks, M.; Traynor, D. Morphogen hunting in Dictyostelium. Development 1989, 107, 81-90. [PubMed]

40. Kay, R.R.; Flatman, P.; Thompson, C.R.L. DIF signalling and cell fate. Semin. Cell Dev. Biol. 1999, 10, 577-585. [CrossRef]

41. Wurster, B.; Kay, R.R. New roles for DIF? Effects on early development in Dictyostelium. Dev. Biol. 1990, 140, 189-195. [CrossRef]

42. Morandini, P.; Offer, J.; Traynor, D.; Nayler, O.; Neuhaus, D.; Taylor, G.W.; Kay, R.R. The proximal pathway of metabolism of the chlorinated signal molecule differentiation-inducing factor-1 (DIF-1) in the cellular slime mould Dictyostelium. Biochem. J. 1995, 306, 735-743. [CrossRef] [PubMed]

43. Cornillon, S.; Foa, C.; Davoust, J.; Buonavista, N.; Gross, J.D.; Golstein, P. Programmed cell death in Dictyostelium. J. Cell Sci. 1994, 107, 2691-2704. [PubMed]

44. Giusti, C.; Tresse, E.; Luciani, M.F.; Golstein, P. Autophagic cell death: Analysis in Dictyostelium. Biochim Biophys Acta 2009, 1793, 1422-1431. [CrossRef]

45. Luciani, M.F.; Kubohara, Y.; Kikuchi, H.; Oshima, Y.; Golstein, P. Autophagic or necrotic cell death triggered by distinct motifs of the differentiation factor DIF-1. Cell Death Differ. 2009, 16, 564-570. [CrossRef]

46. Luciani, M.F.; Giusti, C.; Harms, B.; Oshima, Y.; Kikuchi, H.; Kubohara, Y.; Golstein, P. Atg1 allows second-signaled autophagic cell death in Dictyostelium. Autophagy 2011, 7, 501-508. [CrossRef] [PubMed] 
47. Giusti, C.; Luciani, M.F.; Ravens, S.; Gillet, A.; Golstein, P. Autophagic cell death in Dictyostelium requires the receptor histidine kinase DhkM. Mol. Biol. Cell 2010, 21, 1825-1835. [CrossRef]

48. Kuwayama, H.; Kubohara, Y. Differentiation-inducing factor-1 and -2 function also as modulators for Dictyostelium chemotaxis. PLoS ONE 2009, 4, e6658. [CrossRef]

49. Kuwayama, H.; Kikuchi, H.; Oshima, Y.; Kubohara, Y. Artificial compounds differentially control Dictyostelium chemotaxis and cell differentiation. Cell Struct. Funct. 2011, 36, 21-26. [CrossRef]

50. Kuwayama, H.; Kubohara, Y. Differentiation-inducing factor 2 modulates chemotaxis via the histidine kinase DhkC-dependent pathway in Dictyostelium discoideum. FEBS Lett. 2016, 590, 760-768. [CrossRef]

51. Insall, R.; Kay, R.R. A specific DIF binding protein in Dictyostelium. EMBO J. 1990, 9, 3323-3328. [CrossRef] [PubMed]

52. Kubohara, Y.; Maeda, M.; Okamoto, K. Analysis of the maturation process of prestalk cells in Dictyostelium discoideum. Exp. Cell Res. 1993, 207, 107-114. [CrossRef] [PubMed]

53. Kubohara, Y.; Okamoto, K. Cytoplasmic $\mathrm{Ca}^{2+}$ and $\mathrm{H}^{+}$concentrations determine cell fate in Dictyostelium discoideum. FASEB J. 1994, 8, 869-874. [CrossRef] [PubMed]

54. Chen, Z.H.; Schaap, P. The prokaryote messenger c-di-GMP triggers stalk cell differentiation in Dictyostelium. Nature 2012, 488, 680-683. [CrossRef] [PubMed]

55. Song, Y.; Luciani, M.F.; Giusti, C.; Golstein, P. c-di-GMP induction of Dictyostelium cell death requires the polyketide DIF-1. Mol. Biol. Cell 2015, 26, 651-658. [CrossRef] [PubMed]

56. Kuwayama, H.; Kikuchi, H.; Oshima, Y.; Kubohara, Y. Glutathione S-transferase 4 is a putative DIF-binding protein that regulates the size of fruiting bodies in Dictyostelium discoideum. Biochem. Biophys. Rep. 2016, 8, 219-226. [CrossRef] [PubMed]

57. Kubohara, Y.; Kikuchi, H.; Nguyen, V.H.; Kuwayama, H.; Oshima, Y. Evidence that differentiation-inducing factor-1 controls chemotaxis and cell differentiation, at least in part, via mitochondria in D. discoideum. Biol. Open 2017, 6, 741-751. [CrossRef] [PubMed]

58. Kay, R.R. The biosynthesis of differentiation-inducing factor, a chlorinated signal molecule regulating Dictyostelium development. J. Biol. Chem. 1998, 273, 2669-2675. [CrossRef]

59. Oka, H.; Asahi, K.; Morishima, H.; Sanada, M.; Shiratori, K.; Iimura, Y.; Sakurai, T.; Uzawa, J.; Iwadare, S.; Takahashi, N. Differanisole A, a new differentiation inducing substance. J. Antibiot. 1985, 38, 1100-1102. [CrossRef]

60. Kubohara, Y.; Okamoto, K.; Tanaka, Y.; Asahi, K.; Sakurai, A.; Takahashi, N. Differanisole A, an inducer of the differentiation of Friend leukemic cells, induces stalk cell differentiation in Dictyostelium discoideum. FEBS Lett. 1993, 322, 73-75. [CrossRef]

61. Asahi, K.; Sakurai, A.; Takahashi, N.; Kubohara, Y.; Okamoto, K.; Tanaka, Y. DIF-1, morphogen of Dictyostelium discoideum, induces the erythroid differentiation in murine and human leukemia cells. Biochem. Biophys. Res. Commun. 1995, 208, 1036-1039. [CrossRef]

62. Kubohara, Y.; Saito, Y.; Tatemoto, K. Differentiation-inducing factor of D. discoideum raises intracellular calcium concentration and suppresses cell growth in rat pancreatic AR42J cells. FEBS Lett. 1995, 359, 119-122. [CrossRef]

63. Kubohara, Y. DIF-1, putative morphogen of D. discoideum, suppresses cell growth and promotes retinoic acid-induced cell differentiation in HL-60. Biochem. Biophys. Res. Commun. 1997, 236, 418-422. [CrossRef]

64. Kubohara, Y. Effects of differentiation-inducing factors (DIFs) of Dictyostelium discoideum on the human leukemia K562 cells: DIF-3 is the most potent anti-leukemic agent. Eur. J. Pharmacol. 1999, 381, 57-62. [CrossRef]

65. Kanai, M.; Konda, Y.; Nakajima, T.; Izumi, Y.; Nanakin, A.; Kanda, N.; Kubohara, Y.; Chiba, T. Differentiation-inducing factor-1 (DIF-1) inhibits STAT3 activity involved in gastric cancer cell proliferation via MEK-ERK dependent pathway. Oncogene 2003, 22, 548-554. [CrossRef] [PubMed]

66. Takahashi-Yanaga, F.; Taba, Y.; Miwa, Y.; Kubohara, Y.; Watanabe, Y.; Hirata, M.; Morimoto, S.; Sasaguri, T. Dictyostelium differentiation-inducing factor-3 activates glycogen synthase kinase-3b and degrades cyclin D1 in mammalian cells. J. Biol. Chem. 2003, 278, 9663-9670. [CrossRef] [PubMed]

67. Kubohara, Y.; Kimura, C.; Tatemoto, K. Putative morphogen, DIF, of Dictyostelium discoideum induces apoptosis in rat pancreatic AR42J cells. Develop. Growth Differ. 1995, 37, 711-716. [CrossRef] 
68. Fujimaki, S.; Kubohara, Y.; Kobayashi, I.; Kojima, I. Caspase-independent apoptosis induced by differentiation-inducing factor of Dictyostelium discoideum in INS-1 cells. Eur. J. Pharmacol. 2001, 421, 93-100. [CrossRef]

69. Dubois, A.; Ginet, C.; Furstoss, N.; Belaid, A.; Hamouda, M.A.; El Manaa, W.; Cluzeau, T.; Marchetti, S.; Ricci, J.E.; Jacquel, A.; et al. Differentiation inducing factor 3 mediates its anti-leukemic effect through ROS-dependent DRP1-mediated mitochondrial fission and induction of caspase-independent cell death. Oncotarget 2016, 7, 26120-26136. [CrossRef]

70. Miwa, Y.; Sasaguri, T.; Kosaka, C.; Taba, Y.; Ishida, A.; Abumiya, T.; Kubohara, Y. DIF-1, a morphogen of Dictyostelium, induces G1 arrest and differentiation of vascular smooth muscle cells. Circ. Res. 2000, 86, 68-75. [CrossRef]

71. Kubohara, Y.; Kikuchi, H.; Oshima, Y. Exploitation of the derivatives of Dictyostelium differentiation-inducing factor-1, which promote glucose consumption in mammalian cells. Life Sci. 2008, 83, 608-612. [CrossRef] [PubMed]

72. Kubohara, Y.; Komachi, M.; Homma, Y.; Kikuchi, H.; Oshima, Y. Derivatives of Dictyostelium differentiationinducing factors inhibit lysophosphatidic acid-stimulated migration of murine osteosarcoma LM8 cells. Biochem. Biophys. Res. Commun. 2015, 463, 800-805. [CrossRef] [PubMed]

73. Gokan, N.; Kikuchi, H.; Nakamura, K.; Oshima, Y.; Hosaka, K.; Kubohara, Y. Structural requirements of Dictyostelium differentiation-inducing factors for their stalk-cell-inducing activity in Dictyostelium cells and anti-proliferative activity in K562 human leukemic cells. Biochem. Pharmacol. 2005, 70, 676-685. [CrossRef] [PubMed]

74. Oladimeji, P.; Kubohara, Y.; Kikuchi, H.; Oshima, Y.; Rusch, C.; Skerl, R.; Diakonova, M. A derivative of differentiation-inducing factor-3 inhibits PAK1 activity and breast cancer cell proliferation. Int. J. Cancer Clinic. Res. 2015, 2, 1-6. [CrossRef]

75. Takahashi, K.; Kikuchi, H.; Nguyen, V.H.; Oshima, Y.; Ishigaki, H.; Nakajima-Shimada, J.; Kubohara, Y. Biological activities of novel derivatives of differentiation-inducing factor-3 from Dictyostelium discoideum. Biol. Pharm. Bull. 2017, 40, 1941-1947. [CrossRef] [PubMed]

76. Shimizu, K.; Murata, T.; Tagawa, T.; Takahashi, K.; Ishikawa, R.; Abe, Y.; Hosaka, K.; Kubohara, Y. Calmodulin-dependent cyclic nucleotide phosphodiesterase (PDE1) is a pharmacological target of differentiation-inducing factor-1, an anti-tumor agent isolated from Dictyostelium. Cancer Res. 2004, 64, 2568-2571. [CrossRef] [PubMed]

77. Kubohara, Y.; Kikuchi, H.; Matsuo, Y.; Oshima, Y.; Homma, Y. Mitochondria are the target organelle of differentiation-inducing factor-3, an anti-tumor agent isolated from Dictyostelium discoideum. PLoS ONE 2013, 8, e72118. [CrossRef]

78. Kubohara, Y.; Hosaka, K. The putative morphogen, DIF-1, of Dictyostelium discoideum activates Akt/PKB in human leukemia K562 cells. Biochem. Biophys. Res. Commun. 1999, 263, 790-796. [CrossRef]

79. Akaishi, E.; Narita, T.; Kawai, S.; Miwa, Y.; Sasaguri, T.; Hosaka, K.; Kubohara, Y. Differentiation-inducing factor-1-induced growth arrest of K562 leukemia cells involves the reduction of ERK1/2 activity. Eur. J. Pharmacol. 2004, 485, 21-29. [CrossRef]

80. Takahashi-Yanaga, F.; Sasaguri, T. Drug development targeting the glycogen synthase kinase-3 $\beta$ (GSK-3 $\beta$ )-mediated signal transduction pathway: Inhibitors of the Wnt/ $\beta$-catenin signaling pathway as novel anticancer drugs. J. Pharmacol. Sci. 2009, 109, 179-183. [CrossRef]

81. Yasmin, T.; Takahashi-Yanaga, F.; Mori, J.; Miwa, Y.; Hirata, M.; Watanabe, Y.; Morimoto, S.; Sasaguri, T. Differentiation-inducing factor-1 suppresses gene expression of cyclin D1 in tumor cells. Biochem. Biophys. Res. Commun. 2005, 338, 903-909. [CrossRef] [PubMed]

82. Arioka, M.; Takahashi-Yanaga, F.; Kubo, M.; Igawa, K.; Tomooka, K.; Sasaguri, T. Anti-tumor effects of differentiation-inducing factor-1 in malignant melanoma: GSK-3-mediated inhibition of cell proliferation and GSK-3-independent suppression of cell migration and invasion. Biochem. Pharmacol. 2017, 138, 31-48. [CrossRef] [PubMed]

83. Kubokura, N.; Takahashi-Yanaga, F.; Arioka, M.; Yoshihara, T.; Igawa, K.; Tomooka, K.; Morimoto, S.; Nakatsu, Y.; Tsuzuki, T.; Nakabeppu, Y.; et al. Differentiation-inducing factor-3 inhibits intestinal tumor growth in vitro and in vivo. J. Pharmacol. Sci. 2015, 127, 446-455. [CrossRef] [PubMed] 
84. Omata, W.; Shibata, H.; Nagasawa, M.; Kojima, I.; Kikuchi, H.; Oshima, Y.; Hosaka, K.; Kubohara, Y. Dictyostelium differentiation-inducing factor-1 induces glucose transporter 1 translocation and promotes glucose uptake in mammalian cells. FEBS J. 2007, 274, 3392-3404. [CrossRef] [PubMed]

85. Kawaharada, R.; Nakamura, A.; Takahashi, K.; Kikuchi, H.; Oshima, Y.; Kubohara, Y. Oral administration of Dictyostelium differentiation-inducing factor 1 lowers blood glucose levels in streptozotocin-induced diabetic rats. Life Sci. 2016, 155, 56-62. [CrossRef] [PubMed]

86. Seya, K.; Kanemaru, K.; Matsuki, M.; Hongo, K.; Kitahara, H.; Kikuchi, H.; Oshima, Y.; Kubohara, Y.; Okumura, K.; Motomura, S.; et al. Br-DIF-1 accelerates dimethyl sulphoxide-induced differentiation of P19CL6 embryonic carcinoma cells into cardiomyocytes. Br. J. Pharmacol. 2012, 165, 870-879. [CrossRef] [PubMed]

87. Matsuzaki, E.; Takahashi-Yanaga, F.; Miwa, Y.; Hirata, M.; Watanabe, Y.; Sato, N.; Morimoto, S.; Hirofuji, T.; Maeda, K.; Sasaguri, T. Differentiation-inducing factor-1 alters canonical Wnt signaling and suppresses alkaline phosphatase expression in osteoblast-like cell lines. J. Bone Miner. Res. 2006, 21, 1307-1316. [CrossRef]

88. Kubohara, Y.; Hanaoka, Y.; Akaishi, E.; Kobayashi, H.; Maeda, M.; Hosaka, K. DIF-1, an anti-tumor agent found in Dictyostelium discoideum, inhibits progesterone-induced oocyte maturation in Xenopus laevis. Eur. J. Pharmacol. 2003, 460, 93-98. [CrossRef]

89. Takahashi, K.; Murakami, M.; Hosaka, K.; Kikuchi, H.; Oshima, Y.; Kubohara, Y. Regulation of IL-2 production in Jurkat cells by Dictyostelium-derived factors. Life Sci. 2009, 85, 438-443. [CrossRef]

90. Takahashi, K.; Murakami, M.; Kikuchi, H.; Oshima, Y.; Kubohara, Y. Derivatives of Dictyostelium differentiation-inducing factors promote mitogen-activated IL-2 production via AP-1 in Jurkat cells. Life Sci. 2011, 88, 480-485. [CrossRef]

91. Clayton, J. Chagas disease 101. Nature 2010, 465, S4-S5. [CrossRef] [PubMed]

92. Cançado, J.R. Long term evaluation of etiological treatment of Chagas disease with benznidazole. Rev. Inst. Med. Trop. São Paulo 2002, 44, 29-37. [CrossRef] [PubMed]

93. Coura, J.R.; de Castro, S.L. A critical review of Chagas disease chemotherapy. Mem. Inst. Oswaldo Cruz 2002, 97, 3-24. [CrossRef]

94. Nakajima-Shimada, J.; Hatabu, T.; Hosoi, Y.; Onizuka, Y.; Kikuchi, H.; Oshima, Y.; Kubohara, Y. Derivatives of Dictyostelium discoideum differentiation-inducing factor-3 suppress the activities of Trypanosoma cruzi in vitro and in vivo. Biochem. Pharmacol. 2013, 85, 1603-1610. [CrossRef] [PubMed]

95. Haass, C.; Schlossmacher, M.G.; Hung, A.Y.; Vigo-Pelfrey, C.; Mellon, A.; Ostaszewski, B.L.; Lieberburg, I.; Koo, E.H.; Schenk, D.; Teplow, D.B.; et al. Amyloid beta-peptide is produced by cultured cells during normal metabolism. Nature 1992, 359, 322-325. [CrossRef] [PubMed]

96. Hardy, J. The relationship between amyloid and tau. J. Mol. Neurosci. 2003, 20, 203-206. [CrossRef]

97. Myre, M.A.; Washicosky, K.; Moir, R.D.; Tesco, G.; Tanzi, R.E.; Wasco, W. Reduced amyloidogenic processing of the amyloid beta-protein precursor by the small-molecule Differentiation Inducing Factor-1. Cell Signal. 2009, 21, 567-576. [CrossRef] [PubMed]

98. Kanno, T.; Kubohara, Y.; Goto, F.; Takata, K.; Hayashi, K. NMDA-receptor-dependent and -independent cytotoxic effects of $D$. discoideum differentiation-inducing factor-1 on rat cortical neurons. Develop. Growth Differ. 2001, 43, 709-716. [CrossRef]

99. Matsuda, T.; Takahashi-Yanaga, F.; Yoshihara, T.; Maenaka, K.; Watanabe, Y.; Miwa, Y.; Morimoto, S.; Kubohara, Y.; Hirata, M.; Sasaguri, T. Dictyostelium differentiation-inducing factor-1 binds to mitochondrial malate dehydrogenase and inhibits its activity. J. Pharmacol. Sci. 2010, 112, 320-326. [CrossRef] [PubMed]

100. Takaya, Y.; Kikuchi, H.; Terui, Y.; Komiya, J.; Furukawa, K.I.; Seya, K.; Motomura, S.; Ito, A.; Oshima, Y. Novel acyl a-pyronoids, dictyopyrone A, B and C, from Dictyostelium cellular slime molds. J. Org. Chem. 2000, 65, 985-989. [CrossRef]

101. Kikuchi, H.; Sasaki, K.; Sekiya, J.; Maeda, Y.; Amagai, A.; Kubohara, Y.; Oshima, Y. Structural requirements of dictyopyrones isolated from Dictyostelium spp. in the regulation of Dictyostelium development and in anti-leukemic activity. Bioorg. Med. Chem. 2004, 12, 3203-3214. [CrossRef] [PubMed]

102. Nguyen, V.H.; Kikuchi, H.; Sasaki, H.; Iizumi, K.; Kubohara, Y.; Oshima, Y. Production of novel bispyrone metabolites in the cellular slime mold Dictyostelium giganteum induced by zinc(II) ion. Tetrahedron 2017, 73, 583-588. [CrossRef] 
103. Arai, A.; Goto, Y.; Hasegawa, A.; Hosaka, K.; Kikuchi, H.; Oshima, Y.; Tanaka, S.; Kubohara, Y. Dictyopyrones, novel a-pyronoids isolated from Dictyostelium spp., promote stalk cell differentiation in Dictyostelium discoideum. Differentiation 2005, 73, 377-384.

104. Mareyala, H.B.; Baseeruddin, M.; Reddy, K.S. Formala synthesis of furanodictine B from D-glucose. Tetrahedron Asymmetry 2004, 15, 3457-3460. [CrossRef]

105. Matsuura, D.; Mitsui, T.; Sengoku, T.; Takahashi, M.; Yoda, H. Stereo-divergent synthesis of new amino sugars, furanodictines A and B, starting from D-glucuronolactone. Tetrahedron 2008, 64, 11686-11696. [CrossRef]

106. Ogata, M.; Hattori, T.; Takeuchi, R.; Usui, T. Novel and facile synthesis of furanodictines A and B based on transformation of 2-acetamido-2-deoxy-D-glucose into 3,6-anhydro hexofuranoses. Carbohydr. Res. 2010, 345, 230-234. [CrossRef] [PubMed]

107. Honma, S.; Kouno, K.; Takasaka, S.; Mitazaki, S.; Abe, S.; Kikuchi, H.; Oshima, Y.; Yoshida, M. Effect of brefelamide on proliferation of $1321 \mathrm{~N} 1$ human astrocytoma cells induced by glial cell line-derived neurotrophic factor. Pharmazie 2018, 73, 22-28.

108. Zhang, J.; Yamada, O.; Kida, S.; Matsushita, Y.; Murase, S.; Hattori, T.; Kubohara, Y.; Kikuchi, H.; Oshima, Y. Identification of brefelamide as a novel inhibitor of osteopontin that suppresses invasion of A549 lung cancer cells. Oncol. Rep. 2016, 36, 2357-2364. [CrossRef]

109. Pascapurnama, D.N.; Labayo, H.K.M.; Dapat, I.; Nagarajegowda, D.D.; Zhao, J.; Zhang, J.; Yamada, O.; Kikuchi, H.; Egawa, S.; Oshima, Y.; et al. Induction of osteopontin by dengue virus-3 infection in THP-1 cells-Inhibition of the synthesis by brefelamide and its derivative. Front. Microbiol. 2017, 8, 521. [CrossRef]

110. Saito, T.; Taylor, G.W.; Yang, J.C.; Neuhaus, D.; Stetsenko, D.; Kato, A.; Kay, R.R. Identification of new differentiation inducing factors from Dictyostelium discoideum. Biochim. Biophys. Acta 2006, 1760, 754-761. [CrossRef]

111. Murata, C.; Ogura, T.; Narita, S.; Kondo, A.P.; Iwasaki, N.; Saito, T.; Usuki, T. Synthesis and SAR of 4-methyl5-pentylbenzene-1,3-diol (MPBD), produced by Dictyostelium discoideum. Bioorg. Med. Chem. Lett. 2016, 26, 1428-1433. [CrossRef] [PubMed]

112. Sawada, T.; Aono, M.; Asakawa, S.; Ito, A.; Awano, K. Structure determination and total synthesis of a novel antibacterial substance, AB0022A, produced by a cellular slime mold. J. Antibiot. 2000, 53, 959-966. [CrossRef] [PubMed]

113. Suzuki, T.; Kikuchi, H.; Ogura, M.; Homma, M.K.; Oshima, Y.; Homma, Y. Weight loss by Ppc-1, a novel small molecule mitochondrial uncoupler derived from slime mold. PLoS ONE 2015, 10, e0117088. [CrossRef] [PubMed]

114. Ogura, M.; Kikuchi, H.; Suzuki, T.; Yamaki, J.; Homma, M.K.; Oshima, Y.; Homma, Y. Prenylated quinolinecarboxylic acid derivative suppresses immune response through inhibition of PAK2. Biochem. Pharmacol. 2016, 105, 55-65. [CrossRef] [PubMed]

115. Ogura, M.; Kikuchi, H.; Shakespear, N.B.; Suzuki, T.; Yamaki, J.; Homma, M.K.; Oshima, Y.; Homma, Y. Prenylated quinolinecarboxylic acid derivative prevents neuronal cell death through inhibition of MKK4. Biochem. Pharmacol. 2018, in press. [CrossRef] [PubMed]

(C) 2018 by the authors. Licensee MDPI, Basel, Switzerland. This article is an open access article distributed under the terms and conditions of the Creative Commons Attribution (CC BY) license (http:/ / creativecommons.org/licenses/by/4.0/). 